\title{
CORPORATE FIRST AMENDMENT RightS AFTER CITIZENS UNITED: AN ANALYSIS OF THE POPULAR MOVEMENT TO END THE Constitutional Personhood of CORPORATIONS
}

\author{
Susanna Kim Ripken*
}

\begin{abstract}
One of the most controversial Supreme Court cases last year was Citizens United v. Federal Election Commission. In a sharply divided 5-4 decision, the Court invalidated strict federal campaign finance laws and upheld the First Amendment right of corporations to spend unlimited sums of corporate money to support or oppose candidates in political elections. In response to the case, a grassroots popular movement called for an amendment to the Constitution establishing that money is not speech and that human beings, not corporations, are the only "persons" entitled to constitutional rights. The movement ignited a national campaign to reverse the legal doctrine of corporate personhood, a doctrine that has allowed corporations for the last century to claim the same legal rights as natural persons. By orchestrating a nationwide initiative to amend the Constitution, these grassroots groups hope to follow in the steps of other social justice movements, like the suffragists and the civil rights activists, that successfully organized to demand legal reform. This Article analyzes this burgeoning popular movement and the challenges it faces. The mobilization of these activist organizations raises important questions about the relevance of average citizens' interpretations of constitutional meaning and the role of law in shaping beliefs. This Article uses the doctrine of corporate personhood and the constitutional amendment campaign as points of departure for a broader analysis of the relationships

* Professor of Law, Chapman University School of Law. B.A., Stanford University; J.D., UCLA School of Law. I am grateful to Daniel Bogart, Jeffrey Nesteruk, and Tamara Piety for comments on earlier drafts of this article. Oriana Kim-Rajab and Kelly Regan provided helpful research assistance. Special thanks are owed to Randy Ripken for support throughout all stages of this project.
\end{abstract}


between social movements, constitutional legal reform, and the expressive function of the law. The Article argues that, while the doctrine of constitutional corporate personhood may be indeterminate, it is not irrelevant. In fact, it has a powerful expressive component that molds the way we treat corporations in modern society. 


\section{INTRODUCTION}

Controversial Supreme Court cases often draw national attention and serve as a rallying point for citizens to express their views on important political subjects. One of the most controversial decisions in the Supreme Court's last term was Citizens United v. Federal Election Commission. ${ }^{1}$ In a sharply divided 5-4 decision, the Court invalidated strict federal campaign finance laws and upheld the First Amendment right of corporations to spend unlimited sums of corporate money to support or oppose candidates in political election campaigns. Finding that political speech is constitutionally protected whether it is uttered by an individual or by a corporation, the Court expressly overruled two of its prior First Amendment cases that had upheld prohibitions on corporate expenditures in political elections. ${ }^{2}$

Described as the "most important decision of the term," Citizens United drew widespread negative reaction and fierce criticism from across the country. President Obama lamented, "This ruling strikes at our democracy itself. . . . I can't think of anything more devastating to the public interest." Quickly moving to introduce legislation to reverse the Supreme Court's ruling, Senator Chris Dodd expressed "strong[] disagree[ment] with the Supreme Court's conclusion that money is speech, and that corporations should be treated the same as individual Americans when it comes to protected, fundamental speech rights." Other politicians followed suit, arguing that the holding opens the floodgates for streams of corporate money to pour into politics, drowning out the voices of average citizens. $^{6}$ The Court was accused of partisanship and judicial activism, ${ }^{7}$

1. 130 S. Ct. 876 (2010).

2. Id. at 913 (holding that "[g]overnment may not suppress political speech on the basis of the speaker's corporate identity" and expressly overruling Austin v. Mich. Chamber of Commerce, 494 U.S. 652 (1990) and McConnell v. Fed. Election Comm'n, 540 U.S. 93 (2003)).

3. Erwin Chemerinsky, The Most Important Decision of the Term, TRIAL, May 2010, at 54; Michael Houston, Protecting Corporate and Labor Union Involvement in Elections, ORANGE CNTY. LAWYER, July 2010, at 10 (referring to Citizens United as "one of the most important campaign finance rulings in a century").

4. Sheryl Gay Stolberg, Obama Turns Up Heat Over Ruling on Campaign Spending, N.Y. TimES, Jan. 24, 2010, at A18.

5. Press Release, Senator Christopher S. Dodd, Sen. Dodd Introduces Constitutional Amendment to Reverse Supreme Court Campaign Finance Ruling (Feb. 25, 2010) (2010 WLNR 3913103).

6. See, e.g., Press Release, Senator John Kerry, Kerry Blasts SCOTUS Campaign Finance Decision (Feb. 2, 2010) (2010 WLNR 2190036) ("[T] the system has now been tilted inexorably towards those who have the most money. . . . [T] his Supreme Court went out of its way to unleash the power of corporations in our politics.”). The ruling also met with criticism from academics. See, e.g., Tamara R. Piety, 
and polls showed that the vast majority of Americans opposed the ruling. ${ }^{8}$

Although mainstream criticism of Citizens United has been widely publicized, a lesser known response to the case is a grassroots popular movement calling for an amendment to the United States Constitution establishing that money is not speech and that human beings, not corporations, are the only "persons" entitled to constitutional rights. The movement, called "Move to Amend," was launched immediately after Citizens United was announced and has ignited a campaign to strip corporations of all the constitutional rights they have obtained over the last century. ${ }^{9}$ The Supreme Court never explicitly stated in Citizens United that corporations are "persons" entitled to First Amendment rights; the Court chose instead to frame the issue in terms of whether the speech deserved protection, rather than the speaker. ${ }^{10}$ Critics argue, however, that the unstated premise of the case is that corporations are persons that enjoy the same free speech rights as human citizens. ${ }^{11}$ It is this notion that

Commentary, Citizens United and the Threat to the Regulatory State, 109 Mich. L. REv. FIRST IMPRESSIONS 16 (2010), http://www.michiganlawreview.org/assets/fi/109/piety.pdf (noting the potentially pernicious effect of the case on the commercial speech doctrine); Molly J. Walker Wilson, Too Much of a Good Thing: Campaign Speech after Citizens United, 31 CARDOzo L. REv. 2365, 2369 (2010) (utilizing behavioral science to argue that Citizens United was wrongly decided); Lucian Bebchuk, Citizens United Impact: Corporate Political Speech is Bad for Shareholders, Project Syndicate, (Feb. 23, 2010), http://www.project-syndicate.org/commentary/bebchuk10 /English (stating that "the influence of corporations on politicians and political outcomes can be expected to weaken the rules that protect shareholders and ensure that companies are well-governed.").

7. See, e.g., Tim Rutten, A Partisan Court Unmasked, L.A. Times, Jan. 23, 2010, at A27 (arguing that Citizens United "demonstrates that this is a partisan court, willing to hand down sweeping decisions that ignore decades of jurisprudence based on five Republican votes"); see also Erwin Chemerinsky, Who Are the Judicial Activists Now?, L.A. TIMES, Jan. 22, 2010, at A29 (accusing the conservative justices of "using judicial review to advance the traditional conservative ideological agenda"); Editorial, A First Step in Control of Election \$, BEMIDJI PioneER, Apr. 30, 2010, 2010 WLNR 9007739 (quoting Senator A1 Franken: "Citizens United was an incredible act of judicial activism. It turned back a century of federal law.") (internal quotation marks omitted).

8. A Washington Post-ABC News poll indicated "relatively little difference of opinion on the issue among Democrats (85 percent opposed to the ruling), Republicans (76 percent) and independents (81 percent)." Dan Eggen, Poll: Large Majority Opposes Supreme Court's Decision on Campaign Financing, WASH. Post (Feb. 17, 2010, 4:38 PM), http://www.washingtonpost.com/wpdyn/content/article/2010/02/17/AR2010021701151.html.

9. Move to AmEND, http://www.movetoamend.org (last visited Sept. 24, 2011).

10. Citizens United v. Fed. Election Comm'n, 130 S. Ct. 876, 929 (2010) (Scalia, J., concurring) ("The Amendment is written in terms of 'speech,' not speakers. Its text offers no foothold for excluding any category of speaker .... We are therefore simply left with the question whether the speech at issue in this case is 'speech' covered by the First Amendment.").

11. See Chemerinsky, supra note 3, at 55 (noting that one of the "key premises" of Citizens United is that "corporations have the same free speech rights as citizens"); Nancy 
corporations are persons that is so controversial. The Move to Amend campaign seeks to reverse what it calls the "illegitimate legal doctrine of "Corporate Personhood"' which has allowed corporations to claim to be persons under the law and therefore to claim the same legal rights as natural persons. ${ }^{12}$

Move to Amend is an outgrowth of several activist organizations that have been in existence for some time and that have gained momentum in recent years. Nationwide, well over a hundred grassroots communitybased civil rights and social justice groups have joined the Move to Amend coalition, including the National Lawyers Guild, the Alliance for Democracy, and the Women's International League for Peace and Freedom. $^{13}$ Many of these activist groups revile the dominance of corporate power in modern society. They believe large corporations, with their vast concentrations of wealth and their enormous size, have amassed economic and political power comparable to government power. ${ }^{14}$ Activists see multinational corporations as "governing institutions" that "largely decide what controversies get attention, how wealth is shared and distributed, what solutions are acceptable, who gets elected to public office and how the United States treats other nations."

Price \& David E. Delk, Corporations Are Not People, The Alliance for Democracy, $\mathrm{http} / /$ www.thealliancefordemocracy.org/brochure.pdf (arguing that a "crucial basis for this decision is that corporations, as 'persons,' enjoy free-speech rights") (last visited Sept. 24, 2011); see also Matthew Rothschild, Corporations Aren't Persons, THE Progressive (Apr. 20, 2010), http://www.progressive.org/mrapril10.html (criticizing the Court's declaration that corporations cannot be treated differently under the First Amendment simply because they are not "natural persons") (internal quotation marks omitted).

12. Kaitlin Sopoci-Belknap, Citizens United v. FEC: Supreme Court Sides with Large Corporations, Democracy Unlimited of Humboldt CNTY. (Feb. 28, 2010, 4:30 PM), http://www.duhc.org/profiles/blogs/citizens-united-v-fec-supreme.

13. Organizations, Move TO AMEND, http://www.movetoamend.org/organizations (last visited Sept. 24, 2011). Many of these organizations are themselves extensive coalitions of other progressive organizations, creating a nationwide network of activist groups that support an amendment to the Constitution to abolish corporate personhood. Id.

14. Many scholars agree with this assessment of corporate power. See, e.g., KENT Greenfield, The Failure of Corporate Law: Fundamental Flaws and Progressive PossibILITIES 4-5 (2006) (noting that corporations are among "the largest and most powerful institutions in the world," wielding "the economic power of nations"); Michael Robertson, Property and Ideology, 8 CAN. J.L. \& JURIS. 275, 281 (1995) (arguing that corporate power is like governmental power and that it is misleading to view corporations as private property because of the great power they hold over natural people); Dalia Tsuk, From Pluralism to Individualism: Berle and Means and 20th Century American Legal Thought, 30 LAW \& SOC. INQUIRY 179, 180 n.2 (2005) ("[T]he corporation's economic, social, and cultural impact has become so pervasive in modern society so as to make corporate power, in effect, comparable to the coercive power of the state.").

15. Mission, Democracy Unlmited OF Humbold http://www.duhc.org/page/mission-1; About the Alliance for Democracy, THE AlLIANCE FOR DEMOCRACY, http://www.thealliancefordemocracy.org/about.html ("Major corporations dominate our lives, our government, our work, our health care and our food supply.") 
term profit-maximizing dynamic of the corporation, and they view the relentless pursuit of corporate profit as the greatest cause of political, economic, and ecological injury around the world. The corporate failings that have played a role in the recent financial crisis confirm the dominant nature of large corporations in our lives and our deep dependence on them for our financial welfare.

The grassroots organizations behind the Move to Amend project trace the roots of this corporate power to the legal doctrine of corporate personhood. ${ }^{16}$ Under the law, a corporation is an artificial person; its personhood status is a legal fiction we employ as a convenience to facilitate commerce. ${ }^{17}$ By calling the corporation a person, the law grants it the capacity for legal relations of all kinds. The corporation has standing to enter into contracts, to hold property, to sue and be sued, and ultimately to carry on business in the corporate name. ${ }^{18}$ This legal step does not seem particularly problematic. Activists warn, however, that it leads us down a

(emphasis omitted); see also Lee Drutman \& Charlie Cray, The People’s Business: Controlling Corporations and Restoring Democracy 1-7 (2004) (describing the dominance of corporate power and the fundamental threat it poses to the well-being of our society).

16. While the legal doctrine of corporate personhood has profoundly impacted the way we view corporations, it is by no means the sole lens through which the corporate person can be analyzed. I have described elsewhere the complex nature of the personhood of corporations and the value of evaluating corporate personhood from multiple disciplines. Susanna Kim Ripken, Corporations Are People Too: A Multi-dimensional Approach to the Corporate Personhood Puzzle, 15 FordhAM J. CORP. \& FIN. L. 97 (2009) (analyzing the multi-faceted nature of corporate personhood and proposing a flexible, multi-dimensional model of the corporation).

17. See Jeffrey Nesteruk, Persons, Property, and the Corporation: A Proposal for a New Paradigm, 39 DePaul L. Rev. 543, 564 n.133 (1990) ("A corporation is artificial in that it is a human creation subject to human choices."); James V. Schall, The Corporation: What Is It? , 4 AvE MARIA L. REV. 105, 118 (2006) (describing the corporation as primarily a human invention created for man's use). Legal personhood can be given to just about any object if it is deemed to serve the ends of justice. See, e.g., Richard Tur, The "Person" in Law, in Persons AND Personality: A Contemporary InQuiry 116, 121 (Arthur Peacocke \& Grant Gillett eds., 1987) (referring to a case where an Indian idol was given a legal personality); see also Arthur W. Machen, Jr., Corporate Personality, 24 HARv. L. Rev. 347, 350 (1911) (noting that purely inanimate objects may be personified, e.g., the estate of a deceased person, a jury, or a community). The term "natural person" typically refers to human beings. See Jessica Berg, Of Elephants and Embryos: A Proposed Framework for Legal Personhood, 59 Hastings L.J. 369, 373 (2007) (“"Natural person' is the term used to refer to human beings' legal status.").

18. See, e.g., Model Bus. CORP. ACT $\S 3.02$ (2005) stating:

[E]very corporation has perpetual duration and succession in its corporate name and has the same powers as an individual to do all things necessary or convenient to carry out its business and affairs, including without limitation power: (1) to sue and be sued, ... (4) to . . own, hold, improve, use, and otherwise deal with, real or personal property, ... (7) to make contracts and guarantees .... 
slippery slope. Once the law recognizes the corporation as a person, it does not take much to decide corporations then have legal standing as persons to claim all manner of basic rights, including constitutional rights originally intended for individuals. Indeed, in a series of cases over the last century, the Supreme Court has held corporations are persons entitled to numerous constitutional protections, and the Court has consequently invalidated laws infringing on those corporate rights. ${ }^{19}$ Activists argue that with the shield of constitutional corporate personhood, corporations are able to resist the enforcement of laws, such as environmental and criminal laws, that regulate corporate operations and protect human beings from coercive corporate harm. They fear the corporate creation has now become more powerful than its human creators. The only way to remedy this problem is to take personhood away from corporations and restore power to "We the People" through a constitutional amendment.

The overriding mission of these activist groups is to overthrow "corporate rule" in our society. ${ }^{20}$ I call them Corporate Abolitionists because they see their work as similar to that of the early abolitionists who demanded an end to slavery. One of their widely used slogans resonates with this theme: "Slavery is the legal fiction that a person is property. Corporate personhood is the legal fiction that property is a person."21 The Corporate Abolitionists do not argue that large corporations must be more socially responsible or that we should adopt stricter laws to regulate corporate behavior and reign in corporate power. Instead, the Corporate Abolitionists believe the abolition of corporate personhood is an issue of human rights, like the abolition of slavery. The whole institution is fundamentally wrong and must be eradicated if we are to have true democracy. In mobilizing the grassroots Move to Amend campaign, Corporate Abolitionists feel now is the time for a popular uprising to end the dominance of corporations in our country. In essence, their movement calls for the complete revocation of corporate legal personhood and the unraveling of 125 years of constitutional jurisprudence. By orchestrating a nationwide initiative to add a twenty-eighth amendment to the Constitution, the Corporate Abolitionists hope to follow in the model of other social

19. The Supreme Court first stated that corporations were persons for purposes of the Fourteenth Amendment in Santa Clara v. S. Pac. R.R. Co., 118 U.S. 394, 396 (1886). See discussion of Santa Clara and the Supreme Court's subsequent expansion of corporate constitutional rights infra notes 41-55 and accompanying text.

20. Barbara Clancy, National Meeting Builds Move to Amend Coalition, Move to AMEND (May 20, 2010), http://www.movetoamend.org/news/national-meeting-buildsmove-amend-coalition; Jan Edwards \& Molly Morgan, Abolish Corporate Personhood, RECLAIM DEMOCRACY (May 20, 2004), http://www.reclaimdemocracy.org/personhood/ edwards morgan corporate.html.

21. Molly Morgan \& Jan Edwards, Abolish Corporate Personhood, 59 GulLd PRAC. 209, 214 (2002). 
justice movements, like the suffragists and the civil rights activists, that successfully organized to demand legal reform. ${ }^{22}$

The arguments of the Corporate Abolitionists are intriguing. On the one hand, critics might dismiss these anti-corporate activists as utopians, radicals, or fringe segments of society that condemn large corporations and oppose modern capitalism. Their protests, marches, and rallies are nothing to take too seriously because their goals are extreme and there is little likelihood they will achieve their ultimate objective. On the other hand, the voice of the Corporate Abolitionists is getting louder, and they are gaining more converts to their cause. ${ }^{23}$ They have begun to capitalize on the growing anger and frustration that average citizens feel over the prolonged economic recession, the loss of jobs, excessive executive compensation, and the faltering financial markets. The arguments of the Corporate Abolitionists strike a chord with many Americans whose resentment toward large corporations and Wall Street has only been heightened by the Supreme Court's decision in Citizens United.

The academic literature to this point has not focused significantly on the modern Corporate Abolitionist movement. This Article seeks to bring attention to this burgeoning popular movement and the challenges that it faces. Controversial Supreme Court decisions like the recent Citizens United case can ignite strong public opposition, but it is uncertain whether they can galvanize sufficiently strong social movements to mandate constitutional change. The mobilization of the Corporate Abolitionists in response to Citizens United raises important questions about the relevance of citizens' interpretations of constitutional meaning and the role of the law in shaping beliefs. This Article uses the doctrine of corporate personhood and the Corporate Abolitionists' Move to Amend campaign as points of departure for a much broader analysis of the relationships between social movements, constitutional legal reform, and the expressive function of the law.

Part II of the Article begins with an overview of how corporations came to be called persons under the law. Although the word "corporation" does not appear anywhere in the Constitution, early corporate personhood theories provided a basis for the Supreme Court to declare that corporations are persons for purposes of the Fourteenth Amendment's due process and equal protection clauses. The Fourteenth Amendment was adopted to protect the rights of newly freed slaves, but the formative years of constitutional interpretation of the Fourteenth Amendment were marked by significant expansions of corporate constitutional rights, rather than the

22. Defend Democracy: Join with Us to Abolish Corporate Personhood, Women's INT'L LEAGUE FOR PEACE AND FREEDOM, http://www.wilpf.org/SupremeCtCitizen UnitedDecision (last visited Sept. 24, 2011).

23. See discussion of growing Corporate Abolitionist movement infra Part III. 
rights of African-American individuals. The Supreme Court thereafter interpreted the Constitution to extend rights to corporations in several other contexts, including the First Amendment. Part II describes the development of these corporate constitutional rights and the road leading to the Supreme Court's latest confirmation of corporate free speech rights in Citizens United.

It is this expansion of corporate constitutional rights that makes Corporate Abolitionists so angry. Part III will highlight the Corporate Abolitionists' movement, who they are, how they have framed their arguments, what their work has accomplished, and where they hope their efforts will lead them. How widespread is their message? Can they effectively mobilize the public to support an amendment to the Constitution? In scrutinizing their repertoire of protest, Part III will show that the activities of the Corporate Abolitionists have grown increasingly more visible and their voices are finding audiences prone to listen. The phrase "corporate personhood" is popping into popular culture, ${ }^{24}$ and the Corporate Abolitionists seek to make it a rallying cry.

Part of the problem with the Corporate Abolitionists' strategy, however, is that they place so much weight on that corporate personhood designation. The assumption underlying their Move to Amend campaign is that a constitutional amendment revoking the personhood of corporations will effectively diminish the power of corporations and dramatically transform society. But Part IV suggests that the personhood concept is largely indeterminate and sometimes irrelevant. Legal history reveals that the personhood label has been arbitrarily applied in constitutional law cases, suggesting that the label itself does not dictate necessary outcomes. We could just as easily refer to "the corporation as a right and duty bearing unit," 25 rather than a person, and the corporation would still have all the same rights it has now. In this sense, the personhood designation may not be as weighty a concept as the Corporate Abolitionists think it is.

Nonetheless, the Corporate Abolitionists may be on to something with their focus on personhood. While they may not characterize their argument in these terms, their call to abandon the legal personhood of corporations reflects recognition of the symbolic and expressive function of the law. The Corporate Abolitionists' views are rooted in a legitimate concern about the power of legal labeling to create realities and shape beliefs. Law plays

24. For example, Philosophy Talk, a popular radio show that is broadcast along the West Coast and hosted by two Stanford philosophy professors, recently aired a show on the personhood of corporations on June 20, 2010. The title of the show was "The Corporation as a Person," featuring Robert A. G. Monks, shareholder activist and author of CORPORATE Governance (2008). The Corporation as a Person, Philosophy TAlK (June 20, 2010), http://www.philosophytalk.org/shows/corporation-person.

25. George F. Deiser, The Juristic Person, 57 U. PA. L. ReV. 300, 313 (1909). 
a role in forming prevailing values and understandings. Calling a corporation a person makes it so in our minds. Legal language does not merely describe a state of affairs, but helps to bring that state of affairs into existence. $^{26}$ This linguistic function of law ties into broader questions about the importance of legal labeling in altering our belief system. If the law does more than declare winners and losers, if it changes the way we perceive our world and the worth we place on those who succeed in constitutional litigation, then perhaps it is imperative that we pay close attention to the unspoken signals law sends about social values. As Part V explains, the differing views of the Corporate Abolitionists and their critics reflect differing views of the symbolic nature of law itself. Corporate Abolitionists see the law as a much more comprehensive tool for constructing cognitive categories and creating truth, and in this regard, their emphasis on the personhood designation is not necessarily misplaced.

Part VI concludes that the Corporate Abolitionist movement serves a limited but relevant function in our system of constitutional change. Social movements mold an environment for people to discuss the important constitutional issues of the day. ${ }^{27}$ They give citizens "an opportunity to talk back to institutions of power and to have a voice in the development of constitutional norms." 28 The Corporate Abolitionists' mobilization in response to the Citizens United case reflects collective participation in constitutional interpretation. From the perspective of popular constitutionalism, the legal system needs such participation even if the social movement does not succeed in its ultimate objective.

\section{CONSTITUTIONAL RIGHTS OF CORPORATIONS}

\section{A. Early Corporate Personhood Theories}

The artificial person theory of the corporation dominated American thinking about corporate personhood in the first half of the nineteenth century. ${ }^{29}$ This theory is also referred to as the concession theory. It stated that corporations are legally formed when the state approves their charters, and therefore, the personhood of corporations is merely a government concession. ${ }^{30}$ The classic statement of the theory is found in Chief Justice

26. See infra notes $192-200$ and accompanying text.

27. Jack M. Balkin \& Reva B. Siegel, Principles, Practices, and Social Movements, 154 U. PA. L. REV. 927, 948 (2006).

28. Id. at 946 .

29. William W. Bratton, Jr., The "Nexus of Contracts" Corporation: A Critical Appraisal, 74 CoRnell L. Rev. 407, 434 (1989); Michael J. Phillips, Reappraising the Real Entity Theory of the Corporation, 21 FLA. ST. U. L. REV. 1061, 1065 (1994).

30. See Phillip I. Blumberg, The Corporate Entity in an Era of Multinational Corporations, 15 DEL. J. CORP. L. 283, 292-93 (1990) (discussing the history of the 
Marshall's description of the corporation in Trustees of Dartmouth College v. Woodward: "A corporation is an artificial being, invisible, intangible, and existing only in contemplation of law. Being the mere creature of law, it possesses only those properties which the charter of its creation confers upon it ...."31 The corporation is artificial, fictional, and conditional because it cannot come into being unless and until the law sanctions it.

Corporations during that period required a special act of the state legislature to approve their charters on a case-by-case basis. ${ }^{32}$ States typically granted corporate charters for enterprises that served a public function and met specific social needs, e.g., public utilities, banks, insurers, transportation services, and water works. ${ }^{33}$ "[T] he corporate privilege was granted sparingly; and only when the grant seemed necessary in order to procure for the community some specific benefit otherwise unattainable." 34 Thus, legislative approvals of charters were seen as special grants or privileges by the sovereign, underscoring the view of corporations as concessions of the government. The state played a decisive role in creating corporations and circumscribing their actions within limited spheres of activity. Early charters often contained specific provisions maintaining some measure of control over corporations to protect the public from

concession theory and describing its essential characteristics). The theory has been called several different names, including the state grant theory, the fictitious personality theory, the artificial personality theory, and the concession theory. Ron Harris, The Transplantation of the Legal Discourse on Corporate Personality Theories: From German Codification to British Political Pluralism and American Big Business, 63 WASH. \& LeE L. Rev. 1421, 1424 (2006).

31. Trs. of Dartmouth Coll. v. Woodword, 17 U.S. (4 Wheat.) 518, 636 (1819).

32. See Lawrence M. Friedman, A History of American Law 188-201 (2d ed. 1985) (discussing the evolution of the state legislature's role in granting corporate charters during the nineteenth century).

33. See James W. Hurst, The Legitimacy of the Business Corporation in the Law OF THE UNITED STATES: 1780-1970 17 (1970) ("From the 1780's well into mid-nineteenth century the most frequent and conspicuous use of the business corporation . . . was for one particular type of enterprise, that which we later called public utility and put under particular regulation because of its special impact in the community."); William W. Bratton, Jr., The New Economic Theory of the Firm: Critical Perspectives from History, 41 STAN. L. REv. 1471, 1484 (1989) ("The American states tended to confer charters on businesses that received state franchises . . . and thus were perceived to require regulation outside of the market system."); see also Martha T. McCluskey, The Substantive Politics of Formal Corporate Power, 53 Buff. L. Rev. 1453, 1475 (2006) (noting that the legal power to confer corporate charters was held by the legislature and exercised to confer "special privileges for limited periods and for limited public purposes"). Because corporations were considered bodies created by law for the purpose of attaining some public end, they were therefore "arms of the state." Warren J. Samuels \& Arthur S. Miller, Introduction: Corporate America, in CORPORATIONS AND SOCIETY: POWER AND RESPONSIBILITY 3 (Warren J. Samuels \& Arthur S. Miller eds., 1987) [hereinafter CORPORATIONS AND SOCIETY].

34. Louis K. Liggett Co. v. Lee, 288 U.S. 517, 549 (1933) (Brandeis, J., dissenting). 
abusive corporate practices. ${ }^{35}$

By the mid-nineteenth century, special chartering gave way to general incorporation statutes. Special incorporations for businesses were regarded as the corrupt result of legislative bribery, political favoritism, and monopolistic practices. $^{36}$ In response to public dissatisfaction, states adopted general incorporation statutes allowing businesses to incorporate freely without special grants from the legislature. ${ }^{37}$ The act of incorporation with the state thus became merely a formality of filing and played little role in the personhood of corporations. The idea that corporations existed only because of the concession of the state held far less force and was replaced with the belief that the corporation actually owed its existence to the individuals who formed the corporation to conduct their business. As a result, the artificial person theory of the corporation diminished in relevance over time.

An alternative view of the corporate person arose during the last half of the nineteenth century. The aggregate theory emphasized that the corporation could not be formed without the action and agreement of human beings. In fact, no corporate acts would ever occur without the

35. For example, states often strictly regulated banking activity through limited powers granted in bank charters and through strict construction of those charters by the courts. Gregory A. Mark, The Personification of the Business Corporation in American Law, 54 U. CHI. L. REV. 1441, 1444 (1987). See also McCluskey, supra note 33, at 1478 ("Some legislatures structured corporations to ensure equal voting power for smaller investors; to require favorable treatment of the poor; or to ensure that investors and managers retained private individual responsibility for corporate debts and liabilities."). At times, states even regulated the prices that corporations could charge and the rate of return that investors could earn. Id. at 1476. Courts also tended to support broad state powers over corporations. See, e.g., Leep v. St. Louis, Iron Mountain \& S. Ry. Co., 25 S.W. 75, 81 (Ark. 1894) (holding that even though legislatures lacked power to dictate how natural persons paid their employees, legislatures had the power to do so with corporate employers).

36. See Morton J. Horwitz, Santa Clara Revisited: The Development of Corporate Theory, 88 W. VA. L. REv. 173, 181 (1985) (discussing the movement away from a concession theory of the corporation and towards free incorporation laws "that would break the connection between the act of incorporation and political favoritism"); Mark, supra note 35 , at 1453-54 (discussing the corruption and political favoritism associated with the special privileges of incorporation); see also Christopher D. STONE, WHERE THE LAW ENDS: THE Social Control of CoRPORATE Behavior 20 (1975) (noting that the special charter procedure became increasingly unpopular because of its association with monopoly favors and legislative corruption).

37. See FRIEDMAN, supra note 32, at 512 ("It was cheap and easy to incorporate under general laws - a few papers filed, a few forms and signatures; the privilege of incorporation lay open to whoever wanted it."); Reuven S. Avi-Yonah, The Cyclical Transformations of the Corporate Form: A Historical Perspective on Corporate Social Responsibility, 30 DEL. J. CORP. L. 767, 792 (2005) (discussing the elimination of corrupt special chartering and the subsequent enactment of general incorporation laws "permitting anyone to form a corporation on payment of a fee, without permission by the state legislature"); see also STONE, supra note 36 (noting that by the end of the nineteenth century, general incorporation statutes had displaced special charters entirely). 
human persons who made up the corporate entity. Therefore, the corporation was seen more as a collection, or aggregate, of individuals who agreed to utilize the corporation for their mutual benefit. The aggregate theory maintained that the corporate person has no existence or identity that is separate and apart from the natural persons in the corporation. ${ }^{38}$ The entity is "owned, managed, and administered by people, [and] its so called actions are but manifestations of actions by real persons." 39 It makes no sense to see the corporation literally as a distinct person.

Under this view of the corporate person, "the rights and duties of an incorporated association are in reality the rights and duties of the persons who compose it, and not of an imaginary being." 40 The United States Supreme Court implicitly relied on this view in Santa Clara v. Southern Pacific Railroad Co. when it declared that a corporation is a person for purposes of the Fourteenth Amendment and, thus, its property cannot be taxed differently from the property of individuals. ${ }^{41}$ The underlying reasoning was that the corporation's property was really just the property of the individual shareholders who owned the corporation, and therefore should be protected in the same manner. ${ }^{42}$ "To deprive the corporation of its property ... is, in fact, to deprive the corporators of their property ... . [T] he courts will look through the ideal entity and name of the corporation to the persons who compose it, and protect them ...."43 The interesting thing about the Santa Clara case is that, although it was about taxes, its defining feature was what it casually said about corporate constitutional

38. 1 Victor Morawetz, A Treatise on the Law of Private Corporations $1-2$ (2d ed. 1886) (stating that it is "self-evident that a corporation is not in reality a person or a thing distinct from its constituent parts. The word 'corporation' is but a collective name for the corporators or members who compose [it]."); PATRicia H. Werhane, PERsons, Rights, AND CORPORATIONS 51 (1985) ("Corporations have no reality over and above their constituents, because they are created by and function only because of them.").

39. Donald R. Cressey, The Poverty of Theory in Corporate Crime Research, in 1 Advances in CRiminological Theory 31, 36 (William S. Laufer \& Freda Adler eds., 1989).

40. 1 MORAWETZ, supra note 38 , at 3.

41. Santa Clara v. S. Pac. R.R. Co., 118 U.S. 394 (1886).

42. Morton Horwitz explained that the Court's decision relied on the aggregate theory arguments of John Pomeroy, counsel for the railroad company, and Justice Field in his circuit court opinion in the companion case, San Mateo v. So. Pac. R.R. Co. (The Railroad Tax Cases), 13 F. 722 (C.C.D. Cal. 1882). Horwitz, supra note 36, at 177-78. Justice Field wrote: "It would be a most singular result if a constitutional provision intended for the protection of every person against partial and discriminating legislation by the states, should cease to exert such protection the moment the person becomes a member of a corporation." San Mateo, 13 F. at 744.

43. The Railroad Tax Cases, 13 F. at 747-48, appeal dismissed as moot sub nom. San Mateo v. S. Pac. R.R. Co., 116 U.S. 138 (1885); see also Santa Clara v. S. Pac. R.R. Co., 18 F. 385, 404-05 (C.C.D. Cal. 1883), aff'd, 118 U.S. 394 (1886) (explaining how corporations are groups of associated people that are entitled to the same constitutional protections as individual persons). 
rights. As the next section explains, Santa Clara is regarded as the launching point for the development of corporate personhood status under the Constitution.

\section{B. Development of Corporate Constitutional Personhood}

When the Constitution refers to persons, it does not speak of corporations, but human beings, or natural persons. Large corporations are "something that could not have been even remotely in the minds of the men who drafted the Constitution." announced in Santa Clara that a corporation - in that case, a large railroad company-was a person for purposes of the equal protection clause of the Fourteenth Amendment. ${ }^{45}$ This conclusion was made without explanation or analysis. In fact, the announcement does not appear in the text of the opinion at all. Rather, in the introductory portion of the case, the Reporter's Note states that prior to oral argument the Chief Justice declared from the bench:

The court does not wish to hear argument on the question whether the provision in the Fourteenth Amendment to the Constitution, which forbids a State to deny to any person within its jurisdiction the equal protection of the laws, applies to these corporations. We are all of opinion that it does. ${ }^{46}$

This brief and conclusory statement has been widely criticized for lacking logic, history, and reason to support it. ${ }^{47}$ The text of the Fourteenth Amendment does not include corporations, and there was nothing in the legislative history of the Amendment to indicate corporations were intended to be beneficiaries of its protections. Instead, it was well known that the purpose of the Fourteenth Amendment was to provide procedural

44. Corporations And Society, supra note 33, at 6.

45. Santa Clara, 118 U.S. at 396.

46. Id.

47. See, e.g., John J. Flynn, The Jurisprudence of Corporate Personhood: The Misuse of a Legal Concept, in CORPORATIONS AND SOCIETY, supra note 33, at 131, 133, 136 (arguing that the Court utilized a specious method for recognizing corporate personhood in Santa Clara); Dale Rubin, Corporate Personhood: How the Courts Have Employed Bogus Jurisprudence to Grant Corporations Constitutional Rights Intended for Individuals, 28 QUINNIPIAC L. REV. 523, 552-59 (2010) (arguing that Santa Clara cannot be interpreted as giving corporations rights under the Fourteenth Amendment). Some Supreme Court justices have since challenged Santa Clara's statement that corporations are constitutional persons. See, e.g., Wheeling Steel Corp. v. Glander, 337 U.S. 562, 579-80 (1949) (Douglas, J., dissenting) (“'Persons' in the first sentence plainly include only human beings, for corporations are not 'born or naturalized.' . . . I can only conclude that the Santa Clara case was wrong and should be overruled."); Conn. Gen. Life Ins. Co. v. Johnson, 303 U.S. 77, 90 (1938) (Black, J., dissenting) ("Neither the history nor the language of the Fourteenth Amendment justifies the belief that corporations are included within its protection."). 
and substantive rights for newly freed slaves. ${ }^{48}$ Nonetheless, the Santa Clara pronouncement became the foundation of the corporate personhood doctrine for purposes of constitutional analysis. The Fourteenth Amendment was thereafter interpreted to protect the rights of corporations far more often than it was held to protect black citizens. For the first fifty years after the adoption of the Fourteenth Amendment, more than fifty percent of the Supreme Court cases applying the Fourteenth Amendment involved corporations, and less than one half of one percent involved race discrimination claims. ${ }^{49}$ The Supreme Court repeatedly confirmed corporations were persons within the meaning of the equal protection clause of the Fourteenth Amendment and thus paved the way for corporations to gain additional constitutional rights. ${ }^{50}$

From that point on, the Supreme Court gradually extended rights to corporate persons under several provisions of the Constitution. For example, the Court has held corporations are entitled to Fourth Amendment rights against unreasonable searches and seizures, ${ }^{51}$ Fifth Amendment protection against double jeopardy, ${ }^{52}$ the Seventh Amendment right to a trial by jury, ${ }^{53}$ and importantly for purposes of this Article, First

48. Earl M. Maltz, Civil Rights, The Constitution, and Congress, 1863-1869 93120 (1990); see also Howard J. Graham, Our "Declaratory" Fourteenth Amendment, 7 STAN. L. REV. 3, 5 (1954) (noting that the Fourteenth Amendment synthesized concepts that had "spearheaded the organized antislavery movement's constitutional attack on slavery and racial discrimination").

49. Conn. Gen. Life Ins. Co., 303 U.S. at 90 (noting the Court's vastly disproportionate usage of the Fourteenth Amendment in the first fifty years since its adoption). Many scholars decry this result. See, e.g., Jack M. Balkin, How Social Movements Change (or Fail to Change) the Constitution: The Case of the New Departure, 39 Suffolk U. L. Rev. 27, 53 (2005) (noting "there is something deeply distressing about the fact that an amendment designed to protect the rights of black citizens was soon interpreted to given [sic] them virtually no protection whatsoever and instead gave constitutional protection to corporations").

50. See, e.g., Gulf, Colorado \& Santa Fe Ry. Co. v. Ellis, 165 U.S. 150, 154 (1897) ("It is well settled that corporations are persons within the provisions of the [F]ourteenth [A]mendment of the [C]onstitution of the United States."); Covington \& Lexington Tpk. Rd. Co. v. Sandford, 164 U.S. 578, 592 (1896) ("It is now settled that corporations are persons, within the meaning of the constitutional provisions forbidding the deprivation of property without due process of law, as well as a denial of the equal protection of the laws.").

51. Hale v. Henkel, 201 U.S. 43, 76 (1906); see also Dow Chem. Co. v. United States, 476 U.S. 227, 236 (1986) (observing that a corporation has a reasonable, legitimate, and objective expectation of privacy within the interior of its covered buildings for purposes of the Fourth Amendment).

52. United States v. Martin Linen Supply Co., 430 U.S. 564, 569, 572 (1977). However, the Fifth Amendment privilege against self-incrimination has been denied to corporations on the grounds that it is a purely personal right applying only to natural persons. United States v. White, 322 U.S. 694, 698 (1944).

53. Ross v. Bernhard, 396 U.S. 531, 542 (1970). 
Amendment rights to free speech and freedom of the press. ${ }^{54}$ Expanding "these [constitutional] rights has legitimized corporations as constitutional actors and placed them on a level with humans in terms of Bill of Rights safeguards. ${ }^{.55}$

The corporation's First Amendment right to speak has arguably been the most controversial, and the Supreme Court's recent holding in Citizens United has revived the debate over whether corporations should be considered persons for constitutional purposes. The following discussion provides a closer look at the Citizens United case and discusses the impact it has had since its release.

\section{Corporate Free Speech Rights and Citizens United}

The Supreme Court affirmed and extended the First Amendment speech rights of corporations in Citizens United.$^{56}$ The case dealt with federal campaign finance laws and the ability of corporations to spend money in support of or in opposition to political candidates. ${ }^{57}$

Citizens United was a nonprofit corporation that released a film entitled, Hillary: The Movie, during Hillary Clinton's candidacy for the Democratic presidential nomination in 2008. The movie was "a featurelength negative advertisement that urge[d] viewers to vote against [Hillary] Clinton for President." 58 The corporation wanted to increase the movie's public distribution by making it available through video-on-demand in the days leading up to the primary election, but feared it would violate the federal Bipartisan Campaign Reform Act of 2002 ("BCRA"). ${ }^{59}$ The BCRA prohibits corporations from using general treasury funds to make independent expenditures for "electioneering communication[s]," which are defined as "any broadcast, cable, or satellite communication" that refers to a political candidate for federal office and is made within thirty days of a primary election. ${ }^{60}$ The initial question presented to the Court was whether the BCRA provision applied to the video-on-demand movie. After oral

54. See First Nat'l Bank of Bos. v. Bellotti, 435 U.S. 765, 777 (1978) (noting that the inherent worth of speech does not depend on the identity of its source, whether corporation or individual); Grosjean v. Am. Press Co., 297 U.S. 233, 244, 251 (1936) (recognizing the fundamental nature of First Amendment rights).

55. Carl J. Mayer, Personalizing the Impersonal: Corporations and the Bill of Rights, 41 Hastings L.J. 577, 650-51 (1990).

56. 130 S. Ct. 876 (2010).

57. The Supreme Court has previously held that expenditures of money are a form of political speech, and therefore, restrictions on the ability of a person or group to spend money on political communications during campaigns are constitutionally impermissible. Buckley v. Valeo, 424 U.S. 1, 19 (1976).

58. Citizens United, 130 S. Ct. at 890.

59. Id. at 888 .

60. 2 U.S.C. $\S \S 441 b(b)(2), 434(f)(3)(A)(2005)$. 
argument, however, the Court asked the parties for new briefing to address the much broader question of whether this statute limiting corporations' independent spending in federal elections should be declared unconstitutional.

By a narrow majority, the Court held in a 5-4 decision that the BCRA's ban on corporate campaign expenditures violated the corporation's right to free speech and must be invalidated. The Court reaffirmed that the First Amendment extends to corporations engaging in political speech. According to the Court, "political speech does not lose First Amendment protection "simply because its source is a corporation." ",61 A corporation, just like an individual, can contribute to the marketplace of ideas by expressing opinions and spending money to support or oppose political candidates. The Court rejected the idea that political speech of corporations should be treated differently under the First Amendment simply because corporations are not "natural persons." ${ }^{\text {"62 }}$ Instead, the First Amendment protects all political speech and does not allow restrictions based on a speaker's corporate identity. "Political speech is 'indispensable to decisionmaking in a democracy, and this is no less true because the speech comes from a corporation rather than an individual.",63 To support its conclusion, the Court expressly overruled two of its previous First Amendment cases that had upheld campaign finance laws restricting corporate expenditures, Austin v. Michigan Chamber of Commerce, ${ }^{64}$ and McConnell v. Federal Election Commission. ${ }^{65}$

In Austin, the Supreme Court sustained a Michigan law banning corporate independent expenditures that supported or opposed candidates for state office. The Michigan Chamber of Commerce sought to use general treasury funds to run a newspaper ad supporting a political candidate. The Austin court explained that the structure of corporations facilitates the amassing of immense wealth in corporate treasuries, and that these large aggregations of funds can have distorting effects in the political marketplace when they are deployed to influence elections. ${ }^{66}$ The Austin Court therefore held that "the State ha[d] articulated a sufficiently compelling rationale to support its restriction on independent expenditures by corporations," and the Court sustained the speech prohibition. ${ }^{67}$ Subsequently in McConnell, the Court relied on the anti-distortion interest

61. Citizens United, 130 S. Ct. at 900 (quoting First Nat'l Bank of Bos. v. Bellotti, 435 U.S. 765, 784 (1978)).

62. Id.

63. Id. at 904 (quoting Bellotti, 435 U.S. at 777).

64. 494 U.S. 652 (1990).

65. 540 U.S. 93 (2003).

66. Austin, 494 U.S. at 660.

67. Id. 
articulated in Austin to uphold the same federal campaign finance law at issue in Citizens United, i.e., the BCRA provision restricting corporate independent expenditures. ${ }^{68}$

The majority opinion in Citizens United rejected the anti-distortion rationale recognized in Austin and McConnell. The majority felt it was improper to focus on the economic wealth of corporate speakers and the potential unfair advantage that wealth might afford to corporations in the political marketplace. "The First Amendment's protections do not depend on the speaker's 'financial ability to engage in public discussion." "'69 The Court reasoned that because the First Amendment prohibits the suppression of political speech based on the speaker's identity, it necessarily also forbids limitations on political speech based on a speaker's wealth. ${ }^{70}$ Thus, the Citizens United Court overruled both Austin and McConnell in striking down the BCRA's ban on corporate independent expenditures, thereby solidifying the First Amendment free speech rights of corporations.

Interestingly, the Court never focused on the issue of corporate personhood anywhere in its opinion. The Court never stated that because corporations are persons, they must be treated just like individuals for purposes of the First Amendment. Instead, the Court framed the issue in terms of whether the speech is the type of speech the First Amendment protects, not whether the speaker is the type of person who can claim First Amendment rights. ${ }^{71}$ Because the political speech here is covered by the First Amendment, it does not matter that it is uttered by a corporation rather than a human being.

In his partial dissent, Justice Stevens faults the majority for failing to address the nature of the speaker. He points out that it is constitutionally permissible to regulate speech based on the speaker's identity in many other contexts, e.g., the speech rights of students, prisoners, military personnel, and government employees. ${ }^{72}$ The dissent distinguishes between

68. McConnell, 540 U.S. at 205.

69. Citizens United, 130 S. Ct. at 904.

70. Id. at 905. In addition to rejecting the anti-distortion rationale, the Court also rejected the argument that corporate political speech can be banned to prevent corruption, or the appearance of corruption, of political officials. The Court concluded that independent corporate expenditures do not lead to, or even create the appearance of, corruption. Id. at 908-11.

71. See id. at 929 (Scalia, J., concurring) ("The Amendment is written in terms of 'speech,' not speakers. Its text offers no foothold for excluding any category of speaker . . . We are therefore simply left with the question whether the speech at issue in this case is 'speech' covered by the First Amendment."). This distinction between speech and the speaker draws on the Court's reasoning in First Nat'l Bank of Bos. v. Bellotti, 435 U.S. 765, 783-85 (1978).

72. Citizens United, 130 S. Ct. at 945 (Stevens, J., concurring in part and dissenting in part). For a discussion of the limited free speech rights of students and prisoners, see generally Aaron H. Caplan, Freedom of Speech in School and Prison, 85 WASH. L. REV. 71 
corporations and human beings, and argues that corporations must be seen for what they really are: "[C]orporations have no consciences, no beliefs, no feelings, no thoughts, no desires. Corporations help structure and facilitate the activities of human beings ... and their 'personhood' [is] ... a useful legal fiction. But they are not themselves members of "We the People' by whom and for whom our Constitution was established." When the Framers drafted the First Amendment, it was the free speech of individual Americans they had in mind, not the unlimited expenditures of giant corporations. ${ }^{74}$ Corporations with their vast wealth and economic power have the ability to overpower non-corporate voices and gain special advantages from politicians they support. The dissent characterizes the majority's opinion as "a rejection of the common sense of the American people, who have recognized a need to prevent corporations from undermining self-government ... and who have fought against the distinctive corrupting potential of corporate electioneering ...."

Many people agree with the dissent. Polls showed that well over two thirds of the American public oppose the Citizens United ruling. ${ }^{76}$ President Obama called the case "a major victory for big oil, Wall Street banks ... and the other powerful interests that marshal their power every day in Washington to drown out the voices of everyday Americans." $77 \mathrm{He}$ denounced the decision as a "ruling [that] strikes at our democracy itself." Some federal lawmakers reacted quickly to attempt to undo the Court's holding. The day Citizens United was decided, legislation was proposed in

(2010).

73. Citizens United, 130 S. Ct. at 972 (Stevens, J., concurring in part and dissenting in part).

74. Id. at 950. The dissent cites historical evidence of the suspicion with which corporations were viewed in the founding era and argues that the Framers assumed corporations could be comprehensively regulated for the public welfare. $I d$. at $948-52$.

75. Id. at 979. Criticizing the majority's rejection of the anti-corruption rationale for campaign finance restrictions, the dissent maintains that the enormous power of corporations in federal elections gives rise to the threat of both actual corruption and the public perception of corruption. Id. at 961-68.

76. A Washington Post-ABC News poll indicated that "among Democrats ( 85 percent opposed ... the ruling), Republicans (76 percent) and independents (81 percent)." Eggen, supra note 8.

77. Robert Barnes \& Dan Eggen, Court Rejects Corporate Political Spending Limits, Wash. Post, Jan. 22, 2010, at A1. President Obama called the ruling "a green light to a new stampede of special interest money" and vowed to work with congressional leaders to "develop a forceful response." Id.

78. Stolberg, supra note 4, at A18. In his State of the Union address, with members of the Supreme Court present, President Obama attacked the decision, saying the case "will open the floodgates for special interests . . . to spend without limit in our elections." Robert Barnes, Alito Dissents on Obama Critique of Court Decision, WASH. Post, Jan. 28, 2010, at A6; see also Adam Liptak, A Rare Rebuke, In Front of a Nation, N.Y. TIMES, Jan. 29, 2010, at A12 (noting the unusually public nature of President Obama's criticism of the Supreme Court's decision). 
Congress to prohibit corporations from using operating funds for ads in connection with any federal election campaign. ${ }^{79}$ A few weeks later, Congresswoman Donna Edwards introduced a constitutional amendment to allow Congress and the states to regulate the expenditure of funds by corporations for political speech. ${ }^{80}$

State and local leaders who opposed the Citizens United result also responded in the weeks after the decision was announced. For example, several members of the Alaska state legislature introduced bills to clarify that corporations are not persons for purposes of campaign contributions in public office elections. ${ }^{81}$ The mayor and city council of Berkeley, California, adopted a resolution calling for amending the California Constitution to declare that corporations are not entitled to the rights of persons, that the expenditure of corporate money is not constitutionally protected speech, and to request that other jurisdictions take a similar stand. ${ }^{82}$ Local public rallies were organized by democracy groups around the nation to protest the Citizens United decision. In a "March to Overrule the Court" at the Wisconsin State Capitol, hundreds of people gathered to express their outrage over the decision. ${ }^{83}$ Rally organizers declared, "The Supreme Court didn't give [corporations] a voice, it gave them a megaphone ... What this court did in this case was make [corporations] a master race. They amplified their voice. And supercharged their power." ${ }^{\circledR 4}$

Corporate Abolitionists had been watching the Citizens United case closely. When the decision was announced, they quickly mobilized to form the Move to Amend project. Their goal is to orchestrate a grassroots initiative to convene a national constitutional convention that would adopt

79. H.R.J. Res. 68, 111th Cong. (2010).

80. H.R.J. Res. 74, 111 th Cong. (2010); see also Press Release, Congresswoman Donna F. Edwards, Rep. Edwards, Judiciary Committee Chairman Conyers Introduce Constitutional Amendment to Fix Flawed Supreme Court Ruling on Campaign Finance (Feb. 3, 2010) (2010 WLNR 2203599).

81. H.R. 358-59, 26th Leg., 2d Sess. (Alaska 2010), http://www.legis.state.ak.us/PDF/ 26/Bills/HB0358A.pdf, http://www.legis.state.ak.us/PDF/26/Bills/HB0359A.pdf; see also Press Release, Alaska State Legislature House of Representatives, House Democratic Caucus, Democratic Legislators Seek to Limit Corporate Influence on Elections (Feb. 19, 2010), http://www.akdemocrats.org/gara/022410 note from gara.htm (explaining the motivation behind the proposal of the two bills).

82. Berkeley City Council Res. No. 64,859-N.S., Apr. 27, 2010 (on file with author); Alliance for Democracy, Berkeley Says No "Free Speech" for Corporations (May 6, 2010), http://afd-e-news.blogspot.com/2010/05/berkeley-says-no-free-speech-for.html.

83. Jim Tarbell, Move to Amend: The Campaign for Constitutional Change, JustiCE Rising, Spring 2010, at 2; see also Manski-McCabe-Graves, "Overrule the Court" Rally in Madison, Move TO AMEND (Feb. 16, 2010), http://movetoamend.org/news/manski-mccabegraves-overrule-court-rally-madison (describing the participants of the rally and their goals). The rally was organized by the Wisconsin Democracy Campaign, the Center for Media and Democracy, and the Liberty Tree Foundation for the Democratic Revolution. Id.

84. Manski-McCabe-Graves, supra note 83. 
a constitutional amendment revoking the legal personhood of corporations and thereby strip them of all constitutional rights. The Corporate Abolitionists actually see a silver lining in the Citizens United case: it has become a rallying point for legal reform and a means of bringing attention to their cause. ${ }^{85}$

Who are the Corporate Abolitionists and what is their message? The following Part explores the Corporate Abolitionist movement, its objectives, its accomplishments, and its current attempt to change the meaning of the Constitution.

\section{CORPORATE ABOLITIONISTS}

\section{A. Who They Are and How They Frame Their Arguments}

There are dozens of activist organizations that criticize and condemn what they perceive to be the dominance of corporate power in society. ${ }^{86}$ These Corporate Abolitionist groups ${ }^{87}$ include local community associations and national networks, religious and secular groups, and organizations committed to a broad range of social justice issues. ${ }^{88}$ Many of them share similar mission statements and goals: to "bring[] people together to build a progressive populist movement to end the corporate domination of our economy, our government, our culture, our media and the environment." 89 They seek to link with like-minded groups to form coalitions and networks to increase their visibility. The internet has

85. See Doug Pibel, Real People v. Corporate "People": The Fight Is On, 54 YES! MAGAZINE (May 27, 2010), http://www.yesmagazine.org/issues/water-solutions/real-peoplev.-corporate-people-the-fight-is-on.

86. My description of these activist groups and their arguments draws upon news accounts, social movement scholarship, and other sources, but also relies heavily on the words and writings of the activists themselves. Much of what they say about their work, goals, and methodology is found on their websites.

87. The name 'Corporate Abolitionists' is my term, not theirs. I have grouped many of these organizations together under that label because they share a common interest in revoking the power and status of large corporations by abolishing corporate legal personhood. However, many of these activist groups also have other objectives that are primary to their specific causes, e.g., promoting women's rights, preserving the environment, or restoring local democratic rule.

88. These groups include Alliance for Democracy; Campaign to Legalize Democracy; Community Environmental Legal Defense Fund; Democracy Unlimited of Humboldt County; Liberty Tree Foundation for the Democratic Revolution; Program on Corporations, Law and Democracy; ReclaimDemocracy.org; Redwood Coast Alliance for Democracy; Ultimate Civics; and Women's International League for Peace and Freedom. This list of organizations is not exhaustive. It is merely illustrative of the range of activist groups that are concerned about the role and power of corporations in society.

89. About Alliance for Democracy, The Alliance FOR DemOCRACY, http://www.thealliancefordemocracy.org/about.html (last visited Oct. 18, 2011). 
emerged as a critical mode of communication for these grassroots organizations, allowing them to mobilize and recruit members quickly, and to spread their message to a worldwide audience. ${ }^{90}$ Their websites are often quite comprehensive, linking the reader to numerous books, articles, and sources relating to corporate personhood and its effects on society and the law. ${ }^{91}$

To draw attention to their cause, Corporate Abolitionists engage in a variety of grassroots social movement actions, ${ }^{92}$ including establishing "Abolish Corporate Personhood" affinity groups in local communities; writing letters to the editor and calling talk radio shows to expose the "illegitimacy of corporate personhood;" religious organizations about corporate personhood; circulating petitions to prevent large corporations from moving into their neighborhoods; organizing community-based "democracy schools" and regular "democracy workshops" to educate people about the perils of "corporate rule;", joining

90. Scholars who study modern social movements have noted that the internet has become an important and powerful tool for grassroots organizations. See Barbara B. Woodhouse \& Sarah R. Katz, Martyrs, The Media and the Web: Examining a Grassroots Children's Rights Movement Through the Lens of Social Movement Theory, 5 WhitTIER J. Child \& FAM. Advoc. 121, 160 (2005). "What the shop floor, the neighborhood, or the church was to prior generations of insurgents, the chat room, the email list, and the website may be to this generation." Seth F. Kreimer, Technologies of Protest: Insurgent Social Movements and the First Amendment in the Era of the Internet, 150 U. PA. L. REV. 119, 131 (2001). Cf. Gary W. Selnow, Electronic Whistle-Stops: The ImpaCt of the Internet ON AMERICAN POLITICS 107-13 (1998) (discussing the enormous growth of political websites).

91. See, e.g., ReClaimDemocracy.org, http://www.reclaimdemocracy.org; Program ON CORPORATIONS, LAW \& DEMOCRACY, http://www.poclad.org; WOMEN'S INTERNATIONAL League for Peace and Freedom, http://www.wilpf.org; CoMmunity EnVIRONMENTal Legal Defense Fund, http://www.celdf.org; Redwood Coast Alliance for Democracy, http://www.iiipublishing.com/afd/alliance.htm; CALIFORNIA DEMOCRACY.ORG, http://www.californiademocracy.org; BIG MEDICINE CENTRAL, http://www.nancho.net; Democracy Unlimited OF Humboldt County, http://www.duhc.org; LiberTy Tree FOUNDATION FOR THE DEMOCRATIC REVOLUTION, http://www.libertytreefoundation.org; AMERICAN FriENDS SERVICE COMMITTEe, http://www.afsc.net/ejcorpdem.html; Ultimate Civics, http://www.ultimatecivics.com; CENTER FOR CORPORATE POlicy, http://corporatepolicy.org/index.htm; CENTER FOR MEDIA AND DEMOCRACY, http://www.sourcewatch.org; CITIZEN WORKS, http://citizenworks.org (web sites last visited Sept. 28, 2011).

92. These actions are typical of social movement organizations that use a "repertoire of social movement actions" in an attempt "to shift the existing power balance, to persuade through force of argument, and to enhance their opportunities for civic participation." Jeannie Oakes et. al., Grassroots Organizing, Social Movements, and the Right to HighQuality Education, 4 STAN. J. C.R. \& C.L. 339, 361 (2008).

93. Ten Things You Can Do to Abolish Corporate Personhood, Women's InT'L LeAgue fOR PeACE AND FreEdom (Oct. 10, 2011), http://www.wilpf.org/docs/ccp/corp /ACP/Ten_Things.pdf.

94. The Community Environmental Legal Defense Fund hosts its "Daniel Pennock 
public marches and rallies to promote democracy; even initiating a "walk across the country" to publicize their displeasure with the Citizens United decision. ${ }^{95}$ The Corporate Abolitionist movement combines traditional grassroots efforts to appeal to public opinion and motivate community involvement with a unique legal focus on constitutional reform.

In opposing the proliferation and power of large corporations, Corporate Abolitionists frame their arguments in bold terms:

Major corporations dominate our lives, our government, our work, our health care and our food supply. Media conglomerates control the course and set the limits of public discussion, commercialize and debase our national consciousness, and manipulate mainstream public opinion. Everywhere the natural world is threatened. Yet people worldwide are exhorted to consume more and buy more in the name of "progress" so big corporations can get bigger. ${ }^{96}$

A familiar theme running through the Corporate Abolitionist literature is that corporations have deceived citizens into believing that what is good for corporations is good for America and that corporations are the benevolent sources of jobs, prosperity, liberty, security, and progress. ${ }^{97}$ Corporate Abolitionists contend that large corporations are the cause of devastating social, environmental, and financial harms, and that they are

Democracy Schools" in states all over the country to inform citizens of the "usurpation by corporations of the rights of communities, people, and the earth." What is Democracy School?, Community Environmental Legal Defense Fund (Oct. 10, 2011), http://www.celdf.org/section.php?id=149. Democracy Unlimited of Humboldt County provides a "Challenging Corporate Rule, Creating Democracy Workshop" to give participants "skills and knowledge necessary to reclaim our democracy from corporations." Introductory Workshop, Democracy Unlimited of Humboldt CounTy (Oct. 10, 2011), http:/www.duhc.org/page/introductory-workshop. The Program on Corporations, Law \& Democracy regularly sponsors "Rethinking the Corporation, Rethinking Democracy" workshops to explore "creative new campaigns to oppose corporate claims to constitutional authority." Richard L. Grossman, Wresting Governing Authority from the Corporate Class: Driving People into the Constitution, 1 SEATtLE J. Soc. Just. 147, 159 (2002).

95. Steve Ranson, Lahontan Valley News: Brothers Bring Awareness to Corporate Personhood, MovetoAmend.org (June 3, 2010), http://movetoamend.org/news/lahontanvalley-news-brothers-bring-awareness-corporate-personhood.

96. About Alliance for Democracy, supra note 89 (emphasis omitted).

97. See Grossman, supra note 94, at 155-56 (criticizing the perception that corporations are the source of jobs and progress); Scott McLarty, Fighting Corporate Power in the Wake of the Supreme Court's Citizens United Ruling, MoveToAmend.org (Feb. 13, 2010), $\mathrm{http}$ ://movetoamend.org/news/mclarty-fighting-corporate-power-wake-supreme-courtscitizens-united-ruling (arguing that Americans have been "duped . . . into believing that what's good for insurance companies, Wall Street firms, defense contractors, and other behemoths is good for America"); see also DRUTMAN \& CRAY, supra note 15, at 3 (arguing that corporations "are not the inherently benevolent institutions that they would have us believe that they are" but rather are "very dangerous institutions, capable of causing great harm to society, particularly when left largely unregulated"). 
really "[h]omicidal profit-seeking ... . corporate serial killers," rarely held sufficiently accountable for their wrongdoings. ${ }^{98}$

Corporate Abolitionists believe that stricter regulation of corporate activity is not the solution. They contend that the problem with relying on regulations to check corporate power is that the very nature of that power allows large corporations to influence the legislative and political process of lawmaking itself. Corporations spend millions of dollars annually lobbying for political influence in government. ${ }^{99}$ Corporations are known to give substantial sums of money to both major political parties and to competing political candidates because, in return, corporations presumably gain special access to the officials who are ultimately elected, and with that access, "a disproportionate influence on those in power." 100 The obvious thrust of corporate political activity is to avoid or soften legal regulation of corporate business. Corporations have a role in shaping laws that are intended to regulate their business activity. Utilizing the input of corporations in particular industries, the government adopts standards that are worked out with the industry such that government agencies end up protecting the businesses they are supposed to regulate. ${ }^{101}$ The Corporate Abolitionists argue that the law looks the way it does because of the influence and power of corporations, reflecting the grip corporations have on the political machine and its law-making function. The very law we trust to bind corporations and limit their potential for coercive power is actually formed in significant ways by corporations themselves. ${ }^{102}$

It was not always this way. The Corporate Abolitionists point out that during the earliest years of corporations in America, states strictly limited corporations from gaining the kind of power they have today. State legislatures historically granted special corporate charters to businesses on a case-by-case basis, and these charters typically went only to corporations

98. Bruce A. Dixon, Time for a Corporate Death Penalty, Black AgEnda RePorT (June 9, 2010, 10:35), http://blackagendareport.com/print/content/time-corporate-deathpenalty.

99. Jill E. Fisch, The "Bad Man" Goes to Washington: The Effect of Political Influence on Corporate Duty, 75 FordHAM L. REV. 1593, 1605-07 (2006).

100. Fed. Election Comm'n v. Wis. Right to Life, Inc., 551 U.S. 449, 506 (2007) (Souter, J., dissenting).

101. STONE, supra note 36, at 95, 107 (noting that "when an overseeing agency is in fact staffed with industry personnel" that "[t]he agencies almost all show evidence . . . of protecting the industries they are supposed to regulate, rather than the public"); see also Defying Corporations, Defining Democracy xiv (Dean Ritz, ed. 2001) ("Energy corporations determine our nation's energy policies. Automobile corporations determine our nation's transportation policies ... Corporate polluters and resource extraction corporations define our environmental policies.").

102. Grossman, supra note 94, at 155; Thomas Linzey \& Mari Margil, Whose Rights?, YES! MAGAZINE (Jan. 21, 2010), http://www.yesmagazine.org/people-power/whose-rights. 
serving a public function. ${ }^{103}$ Because a corporation derived its existence from the state, the state could restrict the powers of a corporation for the public interest. ${ }^{104}$ Laws kept corporate power in check by, for example, placing limits on the maximum amount of authorized capital and indebtedness, restricting the life span of corporations to a fixed number of years, and limiting corporations from holding stock in other corporations. ${ }^{105}$ These constraints were imposed out of fear that corporations, if left unbridled, would grow so large and amass such power that they would become oppressive and coercive. ${ }^{106}$ When the Constitution was adopted, the Framers "took it as a given that corporations could be comprehensively regulated in the service of the public welfare."107

Everything changed, however, when the Supreme Court announced for the first time that corporations are persons for purposes of the Fourteenth Amendment. According to the Corporate Abolitionists, that was the tool corporations needed to shift themselves "from the duty side of the line, where they're accountable to the people, to the rights side, where they get protection from government ...." ${ }^{108}$ Corporations thereafter could insert themselves into the text of the Fourteenth Amendment to challenge the validity of any laws adversely affecting their interests: No State shall

103. See supra notes $32-35$ and accompanying text (discussing special chartering system); David Millon, Theories of the Corporation, 1990 DukE L.J. 201, 207 (1990) (explaining that historically corporations were chartered to pursue some sort of public function); see also Timothy L. Fort, Goldilocks and Business Ethics: A Paradigm That Fits "Just Right," 23 J. CORP. L. 245, 260 (1998) (observing that "the strong sense that corporations ought to benefit the public" was rooted in the historical legislative practice of chartering corporations only if the business benefited the public).

104. Many legal opinions reflected this view. See, e.g., Hale v. Henkel, 201 U.S. 43,74 (1904) ("[T]he corporation is a creature of the state. It is presumed to be incorporated for the benefit of the public."). Chief Justice Marshall explained the granting of a charter as an exchange between the corporation and the state: "The objects for which a corporation is created are universally such as the government wishes to promote. They are deemed beneficial to the country; and this benefit constitutes the consideration, and, in most cases, the sole consideration of the grant [of incorporation]." Trs. of Dartmouth Coll. v. Woodward, 17 U.S. 518, 637 (1819); see also A. A. Sommer, Jr., Whom Should the Corporation Serve? The Berle-Dodd Debate Revisited Sixty Years Later, 16 DEL. J. CoRP. L. 33, 36 (1991) (noting that while the organizers of early corporations did expect profits from the business, "the corporations were to serve a public purpose and as such were overseen closely by the state which sanctioned their organization").

105. Louis K. Liggett Co. v. Lee, 288 U.S. 517, 548-56 (1933) (Brandeis, J., dissenting in part).

106. Id. at 548-49. There was "[f]ear of encroachment upon the liberties and opportunities of the individual. Fear of the subjection of labor to capital. Fear of monopoly. ... There was a sense of some insidious menace inherent in large aggregations of capital, particularly when held by corporations." Id.

107. Citizens United v. Fed. Election Comm'n, 130 S. Ct. 876, 949-50 (2010) (Stevens, J., dissenting).

108. Edwards \& Morgan, supra note 20. 
"deprive any person [corporation] of life, liberty, or property, without due process of law; nor deny to any person [corporation] within its jurisdiction the equal protection of the laws." ${ }^{109}$ Corporations were instantly transformed into persons who could compel the state to justify its regulations affecting corporate business. Stretching the meaning of the term 'person' to include corporations meant that other terms in the Fourteenth Amendment also required remolding: "Property'-heretofore tangible property - had to be equated to 'earning power' or 'exchange value' . . . . 'Deprived' in turn, had to mean, not a physical taking, as heretofore, but rather consequential 'diminution' or 'impairment' of exchange value." 110 With this reinterpretation of the Fourteenth Amendment, corporations that had been subject to strict regulation of their operations became the bearer of rights to oppose legislation burdening their interests.

Corporate Abolitionists call this the corporate "[h]ijacking of the Fourteenth Amendment" and trace the consolidation of corporate power to this doctrine of constitutional corporate personhood. ${ }^{111}$ Since then, corporations have steadily gained almost all the inalienable rights of human beings guaranteed by the Bill of Rights. ${ }^{112}$ Corporate Abolitionists warn, "[c] orporations are now a sort of super-being: [ $t$ ]hey can live forever, they cannot be jailed, they have no conscience - yet they also enjoy virtually all the rights that humans have." 113 These same basic rights, combined with corporations' immense wealth and power, allow corporations to overpower individual citizens who consequently become second-class persons with little ability to oppose or resist corporate power, according to the Corporate Abolitionists. ${ }^{114}$

109. U.S. CONST. amend. XIV, § 1.

110. Howard J. Graham, An Innocent Abroad: The Constitutional Corporate "Person", 2 UCLA L. REV. 155, 164-65 (1955).

111. Doug Hammerstrom, The Hijacking of the Fourteenth Amendment, RECLAIMDEMOCRACY.ORG, 1 (2002), http://reclaimdemocracy.org/personhood/fourteenth amendment_hammerstrom.pdf. Some scholars agree with this assessment, calling the extension of the Fourteenth Amendment to corporations "one of the great perverse tragedies in legal history." William Quigley, Catholic Social Thought and the Amorality of Large Corporations: Time to Abolish Corporate Personhood, 5 Loy. J. PuBL. INT. L. 109, 116 (2004).

112. See supra notes 51-55 and accompanying text; see also Daniel J.H. Greenwood, Introduction to the Metaphors of Corporate Law, 4 SEATTLE J. Soc. Just. 273, 276 (2005) ("Our business corporations have virtually every constitutional right against governmental control and regulation humans have ....").

113. Pibel, supra note 85.

114. See William Meyers, The Santa Clara Blues: Corporate Personhood versus Democracy, 17-18 (November 13, 2000), http://reclaimdemocracy.org/pdf/primers/santa clara_blues.pdf ("Because of corporate personhood and corporate constitutional rights, the ordinary, natural person has become a second-class person in the eyes of the law."). This argument finds some support in corporate law scholarship. See, e.g., Mayer, supra note 55, 
In the last several years, Corporate Abolitionists have had some success in communicating their message and mobilizing grassroots efforts to combat corporate personhood and power. One of their strategies has been to work with local governments to pass ordinances abolishing corporate personhood and restricting the rights of corporations in their communities. Over 100 municipalities in Pennsylvania, for example, have passed local laws to abolish the constitutional rights of corporations. ${ }^{115}$ These "anti-corporate personhood" ordinances declare that corporations do not have the same constitutional rights as human beings and can be prohibited by local government from engaging in corporate activities deemed harmful to the community. ${ }^{116}$ Towns in Virginia and Maine have adopted similar ordinances. ${ }^{117}$ In California, voters of Humboldt County a few years ago approved a ballot measure that labeled corporate personhood an "unconstitutional doctrine[]" and prohibited corporations from contributing money in county elections, thereby stripping corporations of First Amendment rights. ${ }^{118}$ In passing this measure, Humboldt County

at 658 (arguing that "the extension of corporate constitutional rights is a zero-sum game that diminishes the rights and powers of real individuals").

115. Channing Joseph, Conservative Pennsylvanians Pass "Radical" Laws Defying U.S. Constitution, THE NEW YORK SUN (July 16, 2007), http://www.nysun.com/article/58464. Residents of these communities have been concerned for years about environmental and physical harms from corporate activities in their towns, including corporate mining, the dumping of sewage sludge, and corporate hog farms. Press Release, Community Environmental Legal Defense Fund, Packer Township, PA, Bans Corporate Sewage Sludge Dumping; Becomes Third Community in Nation to Ban Chemical Bodily Trespass; Strips Corporations of Claim to Constitutional "Rights" (June 12, 2008), http://www.celdf.org/article.php?id=507; Press Release, Community Environmental Legal Defense Fund, Pennsylvania Township is Second to Ban Corporate Mining, Concurrently Adopts Ordinance to Strip Corporations of "Rights" (Dec. 20, 2007), http://www.celdf.org/article.php?id=515; Jane Greer, Communities Fight Back, UnITARIAN UNIVERSALIST AsSOCIATION OF CONGREGATIONS (May 1, 2003), http://www.uuworld.org/ life/articles/157841.shtml ("In Pennsylvania, citizens are mobilizing on several fronts. . . . While some Pennsylvania counties were battling corporate farms, others were lobbying against corporate sewage sludge haulers.").

116. Tom DiStefano, Licking Says Corporations Don't Have "People" Rights, Clarion News (Mar. 12, 2003), http://celdf.org/article.php?id=490; Greer, supra note 115.

117. Alliance for Democracy, Central Maine Town Approves Anti-Corporate Personhood Ordinance (June 16, 2010, 4:31 PM), http://afd-e-news.blogspot.com/2010/06/ central-maine-town-approves-anti.html; Press Release, Community Environmental Legal Defense Fund, Virginia Town First in U.S. to Ban Chemical and Radioactive Bodily Trespass; Also Strips Corporations of "Rights" (Feb. 7, 2008), http://celdf.org/article.php?id=509.

118. For the full text of the ordinance, see Humboldt Coalition for Community Rights, Humboldt County Ordinance to Protect Our Right to Fair Elections and Local Democracy, http://www.votelocalcontrol.org/ordinance_text.htm (last visited Sept. 27, 2011). The local Democratic and Green parties formally endorsed the measure, and it passed with $55 \%$ of the vote. Kaitlin Sopoci-Belknap, Democracy Unlimited: Measure $T$ Bans Corporate Campaign Financing, YES! MAGAZINE (July 29, 2007), 
joined three other California cities-Berkeley, Arcata, and Point Arenathat had previously passed similar resolutions abolishing corporate personhood. ${ }^{119}$ In response to the Supreme Court's ruling in Citizens United, the city of Berkeley recently renewed its resolution to end the constitutional personhood of corporations. ${ }^{120}$

In fact, the Citizens United case has prompted the Corporate Abolitionists to continue with this strategy with even greater fervor. They seek to "grow the grassroots movement to pass municipal legislation and resolutions that defy the Court and strip corporations of their personhood (human rights) status." In doing so, they believe they can "push this

http://www.yesmagazine.org/issues/stand-up-to-corporate-power/democracy-unlimited. The law was later challenged by the Pacific Legal Foundation as unconstitutional for violating corporate rights and was overturned. Organizational History, DeMOCRACy UnLimited of HuMBOLDT COUNTY, http://www.duhc.org/page/organizational-history (last visited Sept. 27, 2011).

119. The Berkeley resolution, adopted on June 15, 2004, stated "the Council of the City of Berkeley supports amending the United States and California Constitutions to declare that corporations are not granted the protections or rights of persons, and . . . to declare that the expenditure of corporate money is not a form of constitutionally protected speech." Berkeley Becomes Latest U.S. Municipality to Oppose Corporate Constitutional "Rights", RECLAIMDEMOCRACY.ORG (June 16, 2004), http://reclaimdemocracy.org/personhood/ berkeley_resolution.html. The Arcata resolution was passed on May 19, 2004, stating "the City Council of the City of Arcata believes that no corporation should be deemed a person and ... no corporation should be entitled to the same rights and protections as those guaranteed only to persons under the U.S. Constitution and Bill of Rights." Resolutions Opposing Corporate Personhood, ReclaimDemocracy.org (May 20, 2004), http://reclaimdemocracy.org/personhood/arcata_pointarena_resolutions.html. The Point Arena resolution, adopted on April 25, 2000, stated "[o]nly natural persons should be able to participate in the democratic process. . . . Rejecting the concept of corporate personhood will advance meaningful campaign finance reform." Id. These resolutions carry no legally binding effect. $I d$. Point Arena recently marked the tenth anniversary of its resolution with a "Democracy Day" community celebration. Jan Edwards, "Democracy Day": $10^{\text {th }}$ Anniversary for Point Arena's Anti-Corporate Personhood Resolution, THE AlLIANCE FOR DeMOCRACY (May 6, 2010), http://afd-e-news.blogspot.com/2010/05/democracy-day-10thanniversary-for.html.

120. See supra note 82 and accompanying text. Corporate Abolitionists have also been able to incorporate their message politically through party platform planks in certain states. In prior years, the Democratic Party in the states of Washington, Oklahoma, New Hampshire and Maine adopted anti-corporate personhood planks as part of their party platforms. Democrats in Washington State Officially Oppose "Money=Speech" Precedent and Corporate Personhood, ReclaimDemocracy.org (June 9, 2004), http://www.reclaimdemocracy.org/political_reform/democratic_party_platform_opposes_bu ckley.html; Oklahoma Democratic Party Opposes Corporate Welfare, Personhood, RECLAIMDEMOCRACY.ORG (June 20, 2004), http://www.reclaimdemocracy.org/personhood/ oklahoma_democrats_oppose_corporate_rights.html; New Hampshire Democrats Oppose "Corporate Constitutional Rights", ReClaimDemocraCy.ORG (May 2004), http://www.reclaimdemocracy.org/personhood/new_hampshire_democratic_oppose_corpor ate_rights.html.

121. Ricki Ott, A Call to Americans: Mobilize and Defy the Court, Justice Rising, Spring 2010, at 12 . 
issue right back to the federal level and force Congress to consider amending the US Constitution" to abolish corporate personhood for good. ${ }^{122}$ The Corporate Abolitionists launched their Move to Amend campaign as another method to accomplish this task. They hope Move to Amend will lead a popular uprising to demand a constitutional amendment that will undo 125 years of constitutional interpretation and "begin the world again." 123

\section{B. "Move to Amend" Campaign in Response to Citizens United}

Corporate Abolitionists are predictably outraged by the Supreme Court's extension of corporate First Amendment rights in Citizens United. Their condemnation of the case has been fierce: "The court's ruling in Citizens United, if left to stand, will destroy whatever hope we may ever have had of democracy in this country. It will entrench corporate power as never before. And the promise of America will be dashed." ${ }^{24}$ While a blow to their cause, Citizens United has actually helped to reinvigorate the Corporate Abolitionists' efforts and strengthened their resolve to lobby for the complete elimination of constitutional protections for corporations. Immediately after the decision was announced, the Move to Amend campaign was formed to launch a grassroots initiative to add a twentyeighth amendment to the Constitution that would abolish corporate personhood. Nationwide, over one hundred community-based civil rights and social justice organizations have joined the Move to Amend coalition. Many of these organizations are themselves extensive coalitions of other progressive groups that together create a national network of activists that support the campaign. ${ }^{125}$

The Move to Amend organizers have crafted the following motion as the centerpiece of their campaign:

We, the People of the United States of America, reject the U.S.

122. Id.

123. Ben Manski \& Lisa Graves, Amend the Constitution to Rein in Corporations, Move TO AMEND (Feb. 12, 2010), http://movetoamend.org/news/manski-and-graves-amendconstitution-rein-corporations.

124. Rothschild, supra note 11.

125. See Organizations, Move TO AMEND, http://movetoamend.org/organizations (last visited Sept. 27, 2011) (listing organizations that support the Move to Amend campaign including, among others, the National Lawyers Guild, the Alliance for Democracy, the Women's International League for Peace and Freedom, the Liberty Tree Foundation for the Democratic Revolution, the Green Party of the U.S., and the Independent Progressive Politics Network). A separate but related campaign that was initiated in response to Citizens United is called FreeSpeechforPeople.org. It also focuses on pushing for a constitutional amendment, but it is narrower in scope, seeking only to limit free speech rights to human beings, rather than tackling the broader issue of corporate personhood. FREESPEECHFOR PEOPLE.ORG, http://www.freespeechforpeople.org/ (last visited Sept. 27, 2011). 
Supreme Court's ruling in Citizens United, and move to amend our Constitution to:

- Firmly establish that money is not speech, and that human beings, not corporations, are persons entitled to constitutional rights.

- Guarantee the right to vote and to participate, and to have our vote and participation count. ... ${ }^{126}$

Ordinary citizens are asked to sign the motion and endorse the effort to effect a fundamental change in the constitutional order. ${ }^{127}$

The Corporate Abolitionists are well aware of what is required to formally amend the Constitution. Article V of the Constitution provides that it may be amended in one of two ways: (1) Congress can pass an amendment with a two-thirds majority in both houses, and then have three quarters of the states ratify it, or (2) two thirds of the states can call a constitutional convention, and then have three quarters of the states ratify the amendment. ${ }^{128}$ Relying more on the second route than the first, the Move to Amend coalition hopes to mobilize a state-led initiative to convene a national constitutional convention. Many within the coalition fear they cannot rely on Congress to move the issue forward and believe it is wiser to put their energy in state initiatives that will trigger a national movement for a constitutional amendment. ${ }^{129}$ In their commitment to a grassroots effort, they believe "genuine change cannot be imposed from the top down. It must proceed from the ground up, and the battles must be waged in local communities." 130

The Corporate Abolitionists argue that the question whether corporations should have the constitutional rights of persons is a political question, one that should be decided by We the People, not a legal question that can be decided by the Supreme Court. ${ }^{131}$ Whether the issue is properly regarded as a political or legal matter is subject to debate, but legal scholars for many years have analyzed at least the question whether corporations should have First Amendment rights as a substantive legal matter. ${ }^{132}$

126. Motion to Amend, Move TO AMEND, http://movetoamend.org/motion-amend (last visited Sept. 27, 2011).

127. Id.

128. U.S. CONST. art. V.

129. See Rothschild, supra note 11 ('I'm not going to rely on Congress. For myself, the safest route is to put all of our energy into the state initiatives and go the constitutional convention route.").

130. Sopoci-Belknap, supra note 118.

131. Challenging Corporate Personhood, Multinational Monitor, Oct./Nov. 2002, at 30,32 .

132. See, e.g., Victor Brudney, Business Corporations and Stockholders' Rights Under the First Amendment, 91 YALE L.J. 235 (1981) (analyzing the relationship among the legal rights of stockholders, corporations' First Amendment rights, and government delegation of 
Support for Corporate Abolitionists' rejection of corporate free speech rights can be found in the work of scholars who argue corporations should be distinguished from individuals under the First Amendment and that free speech rights should not extend equally to corporate persons and natural persons. ${ }^{133}$ They contend that corporations, with their vast economic resources, can speak more loudly than individuals, dominate and distort the debate, silence and exclude other voices, stifle conflicting ideas about politics and society, and ultimately destroy the integrity of the political process. ${ }^{134}$ Corporate campaign spending is simply not the same as human speech, which should be protected as a means of self-expression, selfrealization, and personal fulfillment. ${ }^{135}$ They argue, therefore, that greater

power); Meir Dan-Cohen, Freedoms of Collective Speech: A Theory of Protected Communications by Organizations, Communities, and the State, 79 CAL. L. REV. 1229 (1991) (arguing that the speech of a corporation must be distinguished from, and treated differently than, the speech of individuals); Kent Greenfield et al., Should Corporations Have First Amendment Rights?, 30 SEATTLE U. L. REV. 875 (2007) (debating the question whether corporations should have free speech rights); Charles R. O'Kelley, Jr., The Constitutional Rights of Corporations Revisited: Social and Political Expression and the Corporation after First National Bank v. Bellotti, 67 GEO. L.J. 1347 (1979) (analyzing the complexities of applying First Amendment rights to corporations); Martin H. Redish \& Howard M. Wasserman, What's Good for General Motors: Corporate Speech and the Theory of Free Expression, 66 GEO. WASH. L. REV. 235 (1998) (arguing for the constitutional protection of corporate speech); Bill Shaw et al., Corporate Political Speech and the First Amendment, 9 OKLA. City U. L. Rev. 271 (1984) (questioning whether corporations should have full or limited speech rights).

133. See, e.g., Daniel J.H. Greenwood, Essential Speech: Why Corporate Speech Is Not Free, 83 IowA L. REV. 995, 1004 (1998) (arguing that extending free speech rights to corporations ultimately distorts the political process and is contrary to the goals of the First Amendment); Thomas W. Joo, The Modern Corporation and Campaign Finance: Incorporating Corporate Governance Analysis into First Amendment Jurisprudence, 79 WASH. U. L. Q. 1, 6-7 (2001) (asserting that large corporations are not instruments of individual expression and therefore corporate election-related spending does not deserve the same First Amendment protection enjoyed by individual political spending); William Patton \& Randall Bartlett, Corporate "Persons" and Freedom of Speech: The Political Impact of Legal Mythology, 1981 Wis. L. REV. 494, 509-12 (1981) (arguing that extending First Amendment rights to corporate persons produces results that run counter to the values of the First Amendment). Cf. Mark M. Hager, Bodies Politic: The Progressive History of Organizational "Real Entity" Theory, 50 U. PITT. L. REV. 575 (1989) (arguing that corporations, as collections of capital, should not have the same free speech rights as associations like unions, churches, and citizens' groups that find their purpose in the organization of people).

134. J. M. Balkin, Some Realism About Pluralism: Legal Realist Approaches to the First Amendment, 1990 Duke L.J. 375, 379, 414; Jeffrey Nesteruk, Bellotti and the Question of Corporate Moral Agency, 1988 Colum. Bus. L. REV. 683, 702 ("Central to the conception of the First Amendment is the free marketplace of ideas. . . With unfettered corporate advocacy, the potential exists for this marketplace to be no longer free, but rather to become dominated and controlled.").

135. See Citizens United v. Fed. Election Comm'n, 130 S. Ct. 876, 972 (2010) (Stevens, J., dissenting) (noting that freedom of speech protects individual self-expression and self- 
judicial restraint in corporate challenges to campaign finance laws is not only appropriate but necessary to preserve democratic governance. ${ }^{136}$

Some legal scholars might agree with the Corporate Abolitionists' views about corporations and the First Amendment, and they may even share the same displeasure with the Supreme Court's holding in Citizens United. However, not all of those scholars may likewise be prepared to agree with the Corporate Abolitionists' broader rejection of constitutional corporate personhood and their Move to Amend campaign. One of the country's leading progressive corporate law scholars, Lawrence Mitchell, reportedly stated, "I work with a lot of activist groups, and I sit at meetings banging my head on the table .... [because the doctrine of corporate personhood] is deeply embedded constitutional law that no one's going to reverse." 137 Instead, he suggests that perhaps "activists' energy would be better spent on reforming state laws to make corporations more accountable" rather than working on abolishing corporate personhood entirely. ${ }^{138}$

The Corporate Abolitionists, however, say they are tired of trying to work within the existing legal structure and fix things with regulatory reform. Their sentiment is that it is futile to spend any more "strength, time, and hope ... in such dead ends" "139 as the pursuit of "corporate responsibility, corporate accountability, corporate ethics, corporate codes of conduct, good corporate 'citizenship,' corporate crime, corporate reform, consumer protection, fixing regulatory agencies, or [promoting]

realization); First Nat'l Bank v. Bellotti, 435 U.S. 765, 804-05, 807 (1978) (White, J., dissenting) (observing that corporate speech does not further the principal function of the First Amendment to protect self-expression, self-realization, and self-fulfillment); THOMAS I. EMERson, The System of Freedom of Expression 6 (1970) (discussing the values and functions of freedom of expression); see also Martin H. Redish, The Role of Pathology in First Amendment Theory: A Skeptical Examination, 38 CASE W. RES. L. REV. 618, 627 (1988) (noting the "role of the free speech guarantee as a catalyst in tapping and developing the uniquely human creative and intellectual capacities of the individual").

136. See Balkin, supra note 134, at 386, 414 (arguing that greater judicial restraint in corporate challenges to campaign finance laws is one of the ways in which First Amendment jurisprudence should change). This argument makes a connection between property and speech rights. If "one of the best ways to shut someone up is to impoverish them," then "that is all the more reason to regulate property used to influence the outcome of political campaigns." Id. at 413 .

137. Barry Yeoman, When Is a Corporation Like a Freed Slave?, Mother Jones, Nov. 2006, http://motherjones.com/print/15057 (quoting Lawrence Mitchell). A federal judge reportedly called the anti-corporate personhood arguments of activists "tortured" and "illogical." Id.

138. Id.

139. Richard L. Grossman \& Frank I. Adams, Taking Care of Business: Citizenship and the Charter of Incorporation (1993), available at http://www.ratical.org/corporations /TCoB.pdf. 
stakeholder [interests]."140 To the Corporate Abolitionists, these are all "compromises [that attempt] to make things a little less bad," but they do not address the real root of the problem. ${ }^{141}$ It is not corporate behavior that must be restricted; it is corporate power. What the Corporate Abolitionists seek with their Move to Amend campaign is "transformational law reform," not just incremental legal change. ${ }^{142}$ They believe "[w]e must radically rethink our belief that giant corporations are legitimate parts of our society and return them to their rightful place as subordinate institutions to a sovereign, democratic people."143

In their call to action, the Corporate Abolitionists view their work as similar to that of the abolitionists who successfully labored to end slavery, the suffragists who championed women's rights, the civil rights activists who opposed racial discrimination, and even the American Revolutionaries who resisted political oppression in the name of democratic rule. ${ }^{144}$ The Corporate Abolitionists believe that, like the abolition of slavery, the abolition of corporate personhood is supported by a moral imperative. They argue that the early abolitionists of the nineteenth century did not go to Congress to seek a Slavery Protection Act, or a Slavery Regulatory Agency, or a voluntary code of conduct for slave owners. ${ }^{145}$ The abolitionists viewed the institution of slavery as fundamentally and morally

140. Community Environmental Legal Defense Fund et al., Model Brief of Amici Curiae, Preface (2003), http://www.ratical.org/corporations/demoBrief.pdf. Especially in the wake of Citizens United, the Corporate Abolitionists argue that regulatory reform is not the answer: "Some members of our sadly dysfunctional Congress are calling for a new campaign finance fix. But we've had a century of campaign finance fixes, and look what the Supreme Court has systematically done to them." Manski \& Graves, supra note 123.

141. Citizen Outrage into Citizen Reform, Ultimate Civics, http://www.ultimatecivics.org (last visited Oct. 16, 2011).

142. Cary Coglianese, Social Movements, Law, and Society: The Institutionalization of the Environmental Movement, 150 U. PA. L. REV. 85, 87 (2001).

143. Molly Morgan, Women's Int'l League for Peace and Freedom, Critique of Carly Fiorina, in Organizing Packet for the CAmpaign to Abolish Corporate Personhood 18 (Nov. 7, 2001), http://www.wilpf.org/docs/ccp/corp/ACP/acp-packet.pdf [hereinafter ORGANIZING PACKET].

144. Sopoci-Belknap, supra note 12 ("It's time to follow the lead of the America Revolutionaries, the abolitionists, the suffragists, the trade unionists, and the Civil Rights activists and to build a broad-based, multi-partisan democracy movement in the United States."); Women's InT'L LEAGUe FOR PEACE AND FREEDOM, supra note 22 ("[Abolishing corporate personhood] is as important and challenging as the efforts for Women's Suffrage and the work done to end slavery."); Yeoman, supra note 137 ("People fighting corporate personhood like to think of themselves as heirs to the American Revolution."). Social movements often try to link themselves to prior historical movements and draw on those previous movements' compelling story to buttress the current movement's claims. Thus, the suffragists invoked abolitionist and antislavery rhetoric to give their argument extra persuasive force. Balkin, supra note 49 , at 50 .

145. Morgan \& Edwards, supra note 21, at 213; Ultimate Civics, supra note 141; Yeoman, supra note 137. 
wrong, and therefore, "the whole thing had to go." Corporate Abolitionists insist constitutional corporate personhood must be dismantled if there is any hope of achieving democracy and equal rights. It is an all or nothing proposition. "As long as superhuman "corporate persons' have rights under the law, the vast majority of people have little or no effective voice in our political arena, which is why we see abolishing corporate personhood as so important to ending corporate rule and building a more democratic society." "147 Through the Move to Amend campaign, the Corporate Abolitionists hope to "slay the dragon of corporate personhood once and for all." 148 Like other historical social movements that changed the culture to support a legal strategy to change the law, the Corporate Abolitionists stress the need for a grassroots effort to create a cultural shift in society favoring an amendment to the Constitution.

The Corporate Abolitionists have no illusions about how long it will take to accomplish their objective. They acknowledge it will not be easy to produce cultural changes in thinking, let alone obtain a constitutional amendment. ${ }^{149}$ But they encourage each other with the belief that grassroots anger over the Citizens United case runs high. Drawing inspiration from the powerful social movements of the past that effectuated transformational changes in constitutional meaning, the Corporate Abolitionists declare, "History shows that when the public is sufficiently aroused, actions that once seemed impossible can, in hindsight, seem inevitable." $" 150$

What will happen if the Corporate Abolitionists are successful in abolishing corporate personhood? They claim that once corporate personhood is revoked, corporations will no longer be able to assert any constitutional rights. New laws and stricter regulation of corporate activity will be possible, and corporations will have no standing to challenge these laws. For example, without First Amendment rights, corporations could be prohibited from engaging in campaign spending and other forms of political activity. Without Fourth Amendment rights, government inspectors could more freely search corporate premises and seize corporate

146. Morgan \& Edwards, supra note 21, at 213; see also Meyers, supra note 114, at 24 ("The abolition of corporate personhood is part of the abolition of slavery. ... This is not an optional campaign.”).

147. Edwards \& Morgan, supra note 20.

148. Rothschild, supra note 11.

149. Women's Int'L LeAgUe for PEACE AND FreEdom, supra note 22; The POCLAD Story in Brief, Program on Corporations, LAW \& DeMOCRACy, http://www.poclad.org/?pg=By_What_Authority\&show=b000101.txt (last visited Oct. 16, 2011).

150. Fran Korten, 10 Ways to Stop Corporate Dominance of Politics, YES! MagazINE (Jan. 25, 2010), http://www.yesmagazine.org/people-power/10-ways-to-stop-corporatedominance-of-politics. 
records to ensure compliance with labor laws, environmental laws, or antitrust laws. ${ }^{151}$ Corporate Abolitionists argue corporations could be prohibited from owning stock in other companies and prevented from becoming giant corporate conglomerates. ${ }^{152}$ Communities could ban corporations that exceed a certain size from operating in their towns and rely instead on local businesses and commerce. ${ }^{153}$ Community-controlled corporations and community-based trusts could deliver many essential goods and services. ${ }^{154}$ Corporations would once again be viewed as concessions of the government, subject to strict regulation and privileged to have only the limited rights the state chooses to bestow statutorily. The entire structure of society would be changed if corporations no longer dominated the political, social, and economic landscape. Corporate Abolitionists believe the consequence of abolishing corporate personhood is no less than the resumption of self-governance and the freedom to finally "define our culture as we want to see it." 155

The Corporate Abolitionists' drive for a constitutional amendment may sound extreme, but twenty years ago, then law professor Carl Mayer made the same argument in a law review article that proposed a constitutional amendment to declare corporations are not persons. ${ }^{156} \mathrm{He}$ argued that, without a constitutional amendment favoring individuals over corporations, the Constitution would never "become the exclusive preserve of those whom the Framers sought to protect: 'real' people." 157 More recently, other scholars have made related arguments in favor of abolishing corporate personhood, ${ }^{158}$ or at least ceasing to equate corporate constitutional rights with those of individuals. ${ }^{159}$ In the wake of the

151. Edwards \& Morgan, supra note 20; Meyers, supra note 114, at 18-22.

152. See Women's Int'l League for Peace and Freedom, What Could Change if Corporate Personhood Were Abolished?, in ORGANIZING PACKET, supra note 143, at 15 [hereinafter What Could Change].

153. Meyers, supra note 114, at 20.

154. Charlie Cray \& Lee Drutman, Corporations and the Public Purpose: Restoring the Balance, 4 SeAtTle J. Soc. Just. 305, 308 (2005).

155. Doug Hammerstrom, Why Bother with Corporate Personhood, CAL. CTR. For CMTY. DEMOCRACY, http://www.iiipublishing.com/afd/whybothr.htm.

156. Mayer, supra note 55, at 660-61.

157. Id. at 660 .

158. See, e.g., Quigley, supra note 111, at 109 (arguing that "legal corporation personhood should be abolished" because large corporations are either amoral or immoral). Professor Quigley asserts that corporate regulation has failed to rein in corporations and make them act in ethical and socially responsible ways. Therefore, he believes that the "legal fiction of corporate personhood and the constitutional rights which are given to corporations must cease." Id. at 134.

159. See, e.g., Tamara R. Piety, Against Freedom of Commercial Expression, 29 CARDOZO L. REV. 2583 (2008) (arguing that corporations should be subjected to different standards than human beings when it comes to certain speech rights); Tamara R. Piety, Why the ACLU Was Wrong About Nike, Inc. v. Kasky, 41 Tulsa L. Rev. 715, 725 (2006) 
Supreme Court's opinion in Citizens United, some legal scholars have expressed support for a constitutional amendment but wonder whether it realistically can be achieved. ${ }^{160}$ Rather than dismissing the views of corporate activists as fanatical or subversive, a few legal academics in recent years have promoted strategic linkages between progressive corporate law and progressive social movements. ${ }^{161}$ These linkages may provide broader support for the popular movement the Corporate Abolitionists seek to build in the aftermath of Citizens United.

The strategy of the Corporate Abolitionists' Move to Amend campaign is simple and straightforward: put an end to the legal doctrine of corporate personhood. The weakness in this approach, however, is that the personhood label may not be as determinative or important as the Corporate Abolitionists think. As the next Part explains, with their steadfast focus on the personhood of corporations, Corporate Abolitionists arguably may be barking up the wrong tree.

\section{INDETERMINACY OF THE PERSONHOOD DESIGNATION (OR WHY PERSONHOOD DOES NOT MATTER)}

The Move to Amend campaign is supported by the belief that abolishing corporate constitutional personhood will diminish the legal power of corporations and set the stage for a dramatic transformation of society. The Corporate Abolitionists argue that designating the corporation as a person has elevated the status of corporations and allowed them to claim all the same constitutional rights of natural persons. Once you call the corporation a person, the corporation must be treated in a manner consistent with its membership in the category of persons and afforded the rights to which persons are due. The underlying assumption of this argument is that the term "person" is a concept heavily laden with meaning and that labeling someone a person means certain results must follow. This, however, is a mistaken assumption. Legal history shows that the

(arguing that corporate persons should not be conflated with natural persons for purposes of constitutional rights).

160. Professor Zephyr Teachout reportedly stated, “I'm usually not one for constitutional amendments, but [the Citizens United ruling] calls for one. Of course, if corporations can spend unlimited amounts opposing a constitutional amendment, any effort to enact one will make the 1970s campaign for an Equal Rights Amendment look like a stunning success." Ted Nace, Corporations Unleashed: Landmark Supreme Court Decision to Allow Unlimited Spending in Federal Elections, THE INDYPENDENT (Feb. 19, 2010), http://www.indypendent.org/2010/02/18/corporations-unleashed.

161. See, e.g., Kellye Y. Testy, Linking Progressive Corporate Law with Progressive Social Movements, 76 TuL. L. REV. 1227, 1247-51 (2002) (suggesting that supporters of progressive corporate law should forge alliances with other progressive social movements outside the law). 
personhood designation has been inconsistently applied in constitutional law cases, revealing that the label itself does not dictate results. The extension of constitutional rights to corporations has not been controlled by terminology at all, but by a rather incoherent, ad hoc approach to corporate rights.

The Supreme Court has held corporations are persons for purposes of some constitutional protections but not for others. For example, in extending Fifth Amendment double jeopardy rights to corporations, the Court reasoned that a corporation has the same interests a natural person has in avoiding "embarrassment, expense and ordeal and ... liv[ing] in a continuing state of anxiety and insecurity ...."162 Thus, corporations as persons are entitled to protection from further prosecution and repeated attempts to convict the accused. However, the Supreme Court has declined to extend to corporations the Fifth Amendment privilege against selfincrimination. According to the Court, "[t]he constitutional privilege against self-incrimination is essentially a personal one, applying only to natural individuals. . . . It is designed to prevent the use of legal process to force from the lips of the accused individual the evidence necessary to convict him ....." ${ }^{163}$ The Court has never clearly explained why a corporation is a person for purposes of the double jeopardy clause of the Fifth Amendment, but not for purposes of the self-incrimination clause of the same amendment. ${ }^{164}$ The use of the term "person" in both clauses is analytically indistinguishable. The self-incrimination clause follows immediately after and is grammatically part of the double jeopardy clause, so it is difficult to understand why the self-incrimination privilege is purely personal while the double jeopardy protection is not. It appears constitutional corporate personhood means one thing in one context and something else in another. ${ }^{165}$

At times, the Supreme Court has unabashedly applied this selective approach to corporate personhood and constitutional rights even within the same case. For example, in Hale v. Henkel, the Court simultaneously held

162. United States v. Martin Linen Supply Co., 430 U.S. 564, 569 (1977).

163. United States v. White, 322 U.S. 694, 698 (1944).

164. The Court has tried to make some cognitive peace with this inconsistency by asserting in conclusory terms that certain "purely personal" guarantees like the privilege against self-incrimination are unavailable to corporations because the "historic function" of the particular right has been limited to the protection of individuals. First Nat'l Bank of Bos. v. Bellotti, 435 U.S. 765, 778 n.14 (1978) (internal quotation marks omitted).

165. This selective application of the personhood designation in the context of the Fourteenth Amendment prompted one Supreme Court Justice to remark, "It requires distortion to read 'person' as meaning one thing, then another within the same clause and from clause to clause. It means, in my opinion, a substantial revision of the Fourteenth Amendment." Wheeling Steel Corp. v. Glander, 337 U.S. 562, 579 (1949) (Douglas, J., dissenting). 
corporations are persons entitled to protections from unreasonable searches under the Fourth Amendment, but not persons for purposes of the selfincrimination clause of the Fifth Amendment. ${ }^{166}$ Therefore, the same case both supported and rejected constitutional corporate personhood at the same time for purposes of analyzing different rights under the Constitution.

With respect to the First Amendment, it is clear corporations are persons entitled to First Amendment free speech rights. As Citizens United affirmed, corporations have rights to engage in political speech, to spend corporate money to support or oppose political candidates, and ultimately to have their voice heard in the marketplace of ideas. ${ }^{167}$ In this regard, corporations may not be distinguished from individuals who have the same rights to express their political views and to participate fully in the electoral process. However, the Supreme Court has never held that corporations are persons who have the right to vote, even if they can do everything an individual can do to influence others' votes. Certain rights are restricted to natural persons and cannot be extended to corporate persons.

How can a corporation be a person for one constitutional right, but then stop being a person for another? Once it has been granted the coveted status of a constitutional person, should it not then have standing to claim all the rights and privileges that come with that designation? Perhaps the personhood label is not all it is cracked up to be. The term does not appear to carry as much weight as one might expect. Commentators have suggested "the Supreme Court has used only pragmatic concerns to derive a legal conclusion of constitutional personhood" on a case-by-case basis. ${ }^{168}$ Applying corporate personhood in certain contexts and not in others is a matter of policy and expediency, not a matter of logic or consistent reasoning. The Court extends corporations certain rights under the Constitution because the policy interests at stake make it wise or convenient to do so. When it does not make political sense to give corporations certain constitutional protections, the Court limits the reach of corporate personhood in those areas. ${ }^{169}$

The Supreme Court has never developed a unified theoretical justification for its conclusion that corporations are persons under the Constitution. Thus, there is no coherent, consistent way of defining corporate constitutional rights. The effect is a corporate personhood

166. 201 U.S. 43, 75-76 (1906), overruled in part by Murphy v. Waterfront Comm'n of N.Y. Harbor, 378 U.S. 52 (1964).

167. See supra Part II.C. (discussing Citizens United).

168. Michael D. Rivard, Toward A General Theory of Constitutional Personhood: A Theory of Constitutional Personhood for Transgenic Humanoid Species, 39 UCLA L. REV. 1425, 1465 (1992); see also Bratton, supra note 33, at 1503 (noting the Supreme Court has followed a "situational practice in dealing with questions of corporate constitutional rights for more than a century").

169. Rivard, supra note 168 , at 1431. 
jurisprudence that often seems purely result-oriented. ${ }^{170}$ The Court has utilized conflicting theories of corporate personhood to support particular results, rather than as guiding principles to help reach them. ${ }^{171}$ Corporate personhood is therefore a conclusion, not a question or a starting point from whence conclusions are derived. If this is true, then it does not really matter what we call the corporation. Instead of labeling it a person, we could just as easily refer to it as a "right-and-duty-bearing unit" and give it all the same rights and liabilities it currently carries. ${ }^{172}$ "[I]t becomes [merely] a verbal matter whether we call [corporations] all 'persons,' or whether we . . a abandon the use of the word entirely."173 In other words, the personhood designation is not determinative and is arguably irrelevant.

The Corporate Abolitionists attack corporate personhood so vehemently because they assume that as soon as you call something a person, you must give it the rights accorded to persons. It turns out it is really the other way around. We choose to extend corporations certain rights under the Constitution, whether it be First Amendment free speech rights or Fourteenth Amendment equal protection rights, and in doing so, we then conclude that corporations are persons under the Constitution for purposes of those rights. In this sense, the term person signifies whatever the law makes it signify. A person is whatever the courts say it means and has the rights and duties that courts decide it should have. ${ }^{174}$ "In this sense anything can be made a legal unit, and the subject of rights and duties .... [T] he law [can] accord to the last rose of summer a legal right not to be plucked." 175

If the personhood label does not matter much and carries so little weight, then the Corporate Abolitionists' call to revoke corporate personhood under the Constitution may be misplaced. Due to its

170. Jess M. Krannich, The Corporate "Person": A New Analytical Approach to a Flawed Method of Constitutional Interpretation, 37 Loy. U. CHI. L.J. 61, 64 (2005); Note, What We Talk About When We Talk About Persons: The Language of a Legal Fiction, 114 HARV. L. REV. 1745, 1754 (2001) [hereinafter What We Talk About].

171. Blumberg, supra note 30 , at 318 .

172. John Dewey, The Historic Background of Corporate Legal Personality, 35 YALE L.J. 655, 656 (1926); see also Tara J. Radin, 700 Families to Feed: The Challenge of Corporate Citizenship, 36 VAND. J. TRANSNAT'L L. 619, 651 (2003) (“Treating corporations as legal 'persons' ... allows the legal system to enforce rights and responsibilities for the corporation.").

173. Dewey, supra note 172, at 662.

174. Id. at 655-56; see also Tur, supra note 17, at 121 (arguing that "the concept of legal personality is wholly formal. It is an empty slot that can be filled by anything that can have rights or duties").

175. Gerard Carl Henderson, The Position of Foreign Corporations in American CONSTITUTIONAL LAW 166 (1918). As one commentator noted about the indeterminacy of the personhood term, "[i] ssues do not properly turn upon a name." Bryant Smith, Legal Personality, 37 YALE L.J. 283, 298 (1928). 
indeterminacy, corporate personhood is not as powerful a doctrinal force as the Corporate Abolitionists seem to believe. Therefore, abolishing the legal concept of corporate personhood may not effectuate the changes Corporate Abolitionists hope to achieve. In focusing their efforts on instigating a popular movement to adopt a constitutional amendment to end corporate personhood, the Corporate Abolitionists have attached a level of meaning to the personhood designation that does not appear to be there.

Nonetheless, the Corporate Abolitionists might respond that, even if corporate personhood is indeterminate and manipulable, it is still a powerful legal doctrine that sends the wrong message about the place corporations should hold in our society. In this regard, the Corporate Abolitionists' emphasis on the corporate personhood label is rooted in a deeper concern about the statements law makes about the intrinsic value of people and objects. Although Corporate Abolitionists might not characterize their argument in these terms, their call to abandon the personhood of corporations reflects a belief in the symbolic content of the corporate personhood doctrine and the overall expressive function of the law. The following section discusses this expressive aspect of law and argues that Corporate Abolitionists' concerns about the effects of legal labeling may not be entirely off the mark.

\section{EXPRESSIVE FUNCTION OF LAW (OR WHY PERSONHOOD DOES MATTER)}

Law has the capacity to do much more than control behavior through sanctions. One of law's most powerful functions is to send messages, make statements, and express certain beliefs and attitudes about societal values. ${ }^{176}$ Under an expressive theory of law, "law works by what it says in addition to what it does." 177 For example, sentencing laws that punish criminal behavior express society's moral condemnation of certain acts, making a statement about the kinds of conduct the community views as reprehensible. ${ }^{178}$ Government policies that appear to endorse a particular

176. Alex Geisinger, A Belief Change Theory of Expressive Law, 88 IowA L. REV. 35, 40 (2002); Cass R. Sunstein, On the Expressive Function of Law, 144 U. PA. L. REV. 2021, 2024 (1996).

177. Richard H. McAdams, A Focal Point Theory of Expressive Law, 86 VA. L. ReV. 1649,1651 (2000). For empirical studies of the expressive function of the law, see for example Richard H. McAdams \& Janice Nadler, Testing the Focal Point Theory of Legal Compliance: The Effect of Third-Party Expression in an Experimental Hawk/Dove Game, 2 J. EMPIRICAL Legal StUdies 87, 87 (2005) (suggesting that law can lead to compliance by way of "facilitating coordination around a focal outcome").

178. See Dan M. Kahan, Social Influence, Social Meaning, and Deterrence, 83 VA. L. REV. 349, 362 (1997) (arguing that "social meaning" is central to criminal law, and the manner in which criminal law punishes can give one an insight into society's moral 
religion violate the Establishment Clause, in part because they "send[] a message to nonadherents that they are outsiders, not full members of the political community . . . ."179 Laws that previously legalized racial segregation were invalidated under the Fourteenth Amendment because, among other things, they communicated the harmful message that minority groups were inferior, disfavored members of society. ${ }^{180}$ Law by its nature has expressive elements, and we are necessarily affected by the social and symbolic meaning of legal doctrines and decisions. ${ }^{181}$

Law makes important statements about the intrinsic and relative value of things. ${ }^{182}$ In the context of corporate personhood, for example, the law communicates who counts as a legal person and tells us whether corporations hold the same place as individuals under our legal system. In upholding corporate rights under the First Amendment, the law sends the message that corporate speech and individual speech have the same worth and are deserving of the same protections. Thus, legal doctrine signals the value we as a society place on people, organizations, and certain actions such as speech: "When law uses the metaphor 'person' to define its object, that metaphor acts as a vehicle for expressing beliefs and values about persons, both legal and natural." 183

Beyond merely reflecting societal views and judgments, the law actually helps form prevailing values and understandings. ${ }^{184}$ It shapes perceptions and affects the way people interpret the world around them. ${ }^{185}$

compass); see also Samuel W. Buell, The Blaming Function of Entity Criminal Liability, 81 IND. L.J. 473, 498 (2006) ("The legal judgment's purpose is, in part, to say that the conclusion of blameworthiness sweeps socially ... . [B]ecause legal process . . speaks in this authoritative way, its expression gets attention ...."); Sunstein, supra note 176, at 2023 (" $[\mathrm{M}]$ any people who endorse capital punishment would not be much moved by evidence that capital punishment does not deter people from committing crimes. Their primary concern is the symbolic or expressive content of the law, not aggregate murder rates.").

179. Lynch v. Donnelly, 465 U.S. 668, 688 (1984) (O'Connor, J., concurring).

180. Brown v. Bd. of Educ., 347 U.S. 483 (1954); see also Elizabeth S. Anderson \& Richard H. Pildes, Expressive Theories of Law: A General Restatement, 148 U. PA. L. REV. 1503, 1542-44 (2000) (discussing the expressive dimensions of Brown v. Bd. of Educ.).

181. Robert Nozick, The Nature of Rationality 30 (1993).

182. See, e.g., Sunstein, supra note 176, at 2045-46 (noting that environmental emissions trading laws arguably make a statement about the value of environmental amenities). Critics claim emissions trading has the damaging effect of making people see the environment as a commodity that can be priced, rather than something with intrinsic value that requires public protection. Id. The controversy surrounding flag burning laws reflects similar concerns about the statement law makes regarding the value of patriotism, veterans, and dissidents in our society. Kahan, supra note 178, at 363; Sunstein, supra note 176 , at 2023.

183. What We Talk About, supra note 170, at 1761.

184. David A. Dana, The Law and Expressive Meaning of Condemning the Poor after Kelo, 101 Nw. U. L. REV. 365, 378 (2007); Joo, supra note 133, at 66.

185. Yuval Feldman \& Orly Lobel, The Incentives Matrix: The Comparative Effectiveness of Rewards, Liabilities, Duties, and Protections for Reporting Illegality, 88 
When the law says a certain activity is proper or improper, it molds and changes the beliefs people hold about that activity. Legal labels have a powerful effect in this regard. For instance, racial school segregation laws that had the abhorrent effect of labeling black children as inferior also arguably shaped what those children believed about their worth. As these children internalized the stigma created by discriminatory laws, they viewed themselves in the negative light that the law cast upon them. ${ }^{186}$ Segregation inflicted serious damage to children's self-esteem in part because the law unjustly stamped them with a label of inferiority, which in turn arguably framed their beliefs about themselves and how they related to the social world. ${ }^{187}$ The signals sent by the law influence people's judgments and actions. Legal labeling can not only create cognitive categories but can also "produce behavior that confirms the law's cognitive categories ...."188

In a significant sense, law is meaningful in the way that language is meaningful: "How we describe something [in our choice of words] is an important part of how we perceive it." ${ }^{189}$ Language as a system of discourse conditions the way people think about things. When the law endorses and promotes certain theories of the corporate entity, the law affects our perceptions of the corporation and encourages us to view it in a particular light. ${ }^{190}$ The vocabulary the law uses to characterize corporations

Tex. L. Rev. 1151, 1184 (2010); Keith E. Whittington, Once More Unto the Breach: PostBehavioralist Approaches to Judicial Politics, 25 LAW \& Soc. INQUIRY 601, 621 (2000); see also Danielle Keats Citron, Law's Expressive Value in Combating Cyber Gender Harassment, 108 MicH. L. REV. 373, 409 (2009) (demonstrating how laws have helped alter people's perceptions of domestic violence from a private family matter to criminal conduct).

186. This was the point of the "doll studies" which showed that black children, given a choice, preferred white dolls over darker ones, arguably indicating shame over their own skin color. See Richard Kluger, Simple Justice: The History of Brown v. BoArd of Education and Black America's Struggle for Equality 317-19 (Alfred A. Knopf 1976).

187. Brown v. Bd. of Educ., 347 U.S. 483, 494 (1954); KLUGER, supra note 186, at 70506; see also Woodhouse \& Katz, supra note 90, at 126-27 (discussing the landmark nature of Brown v. Bd. of Educ. because the Supreme Court relied on social science evidence showing children's negative psychological responses to segregation).

188. Mark C. Suchman, On Beyond Interest: Rational, Normative and Cognitive Perspectives in the Social Scientific Study of Law, 1997 WIS. L. REV. 475, 492 (1997). In fact, legal labels can "produce significant behavioral effects, evoking both internal identities and external expectations that channel the labeled actor into conduct that reconfirms the validity of the label." Id. at 491-92.

189. Ellen A. Peters, Reality and the Language of the Law, 90 YALE L.J. 1193, 1195 (1981). For example, "[d]epression is inherently more worrisome than sadness; due and deliberate speed is inherently more deliberate than due." Id. Thus, language has a labeling function that is an integral feature of law as language. $I d$.

190. Millon, supra note 103, at 242; Jeffrey Nesteruk, The Moral Status of the Corporation: Comments on an Inquiry, 2 Bus. ETHICs Q. 461, 463 (1992). 
alters the manner in which we relate to them. Because the "use of particular language has a cultural force of its own," identifying the corporation as a person induces us to associate the attributes of a corporation with those of natural persons. ${ }^{191}$ Perhaps we are cognitively more prone to view the corporation as a person and to treat it with the same deference that persons are due because the law has named it as such.

Language does more than merely describe a state of affairs. Through its ability to influence thought and discussion, it helps "bring that state of affairs into existence." "192 This is because "[i]nstitutions are very much dependent on language: what we cannot imagine and express in language has little chance of becoming a sociological reality."193 This creative aspect of legal language is what makes it so profound. The law not only reflects and incorporates pre-existing social conditions and relations. It also has the capacity to establish new ones. ${ }^{194}$ The law tells us whether a piece of paper is a security, whether a person is an employee, and whether workplace teasing constitutes sexual harassment. By doing so, the law transforms each of these items into a social and legal fact. In this regard, the law creates truth, or makes things true in the eyes of the law. ${ }^{195}$ When the law creates institutions or devices like a corporation or a 401(k) plan, it brings into existence something that is real and true from the standpoint of the law. ${ }^{196}$ If the law says the corporation is now a person, that personhood becomes real and carries consequences that did not previously exist. The corporation becomes a person under the law, but it is also a person as a sociological reality; we think and talk about the corporate person as if it were one of us. When courts create a legal doctrine that says corporate money is speech, the expenditure of money becomes speech, and that also is a legal truth. ${ }^{197}$ It does not matter whether we initially disagree, or believe it is false, or think that type of speech drowns deliberative discussion and displaces democracy. Over time, we are apt to see the world through the law's eyes because it "tends to push [our] imaginations in one direction rather than in another. It opens up some possibilities for thinking while foreclosing others." 198 In this manner, law is "constitutive"

191. Blumberg, supra note 30, at 324; see also DRUTMAN \& CRAY, supra note 15 , at 75 ; Mark, supra note 35, at 1478.

192. What We Talk About, supra note 170, at 1766.

193. Robert N. Bellah et AL., The Good Society 15 (1991).

194. Jeffrey Nesteruk, Law and the Virtues: Developing a Legal Theory for Business Ethics, 5 Bus. ETHICs Q. 361, 362 (1995).

195. Jack M. Balkin, The Proliferation of Legal Truth, 26 HARV. J.L. \& PuB. PoL'y 5, 6 (2003).

196. Id. at 6-7. When the law authorizes the creation of these items, it "is helping to make things in the world" that did not exist previously. Id. at 11 .

197. Id. at 7.

198. Id. at 10. "Law has power over people's imaginations and how they think about 
because it forms the mental frames, categories, and schema individuals use to comprehend and construct the social world. ${ }^{199}$ The ability to shape people's perceptions and understandings of the world around them "is one of the most important forms of power that law possesses."200

While Corporate Abolitionists may not articulate their position in precisely these terms, it is this expressive and constitutive power of law that concerns them the most. From their perspective, the legal doctrine of corporate personhood sends the message that corporations count as persons in our society, that they possess the worth of a person under our law, and that they deserve the same rights and respect natural persons are accorded in a civilized world. Corporate Abolitionists argue this is the wrong message to send. They believe the language of corporate personhood reflects an inappropriate valuation of corporations vis-à-vis human beings. When the Supreme Court announces in cases such as Citizens United that corporations should not be distinguished from individuals while engaging in certain activities like speech, the Corporate Abolitionists contend such legal pronouncements disvalue human beings by improperly placing too much value on corporations. After all, a corporation is a human creation, designed to serve the interests of its creators. Corporate Abolitionists seek to end the legal personhood of corporations to stop the Supreme Court from continuing to send what they believe is a harmful message. ${ }^{201}$

More fundamentally, because law and legal labels have the capacity to modify people's perceptions and judgments, Corporate Abolitionists want to reconstruct the law to change the way people think about corporations. Labeling the corporation as a person makes it so in our minds. Corporate Abolitionists fear that this legal label causes people to internalize the notion that corporations are persons with the same constitutional status and entitlements. If we referred to corporations not as constitutional persons

what is happening in the world." $I d$. at 7 . In some respects, this power over the imagination may arguably have certain ideological effects on individual thinking. Id. at 10 .

199. Richard H. McAdams, The Expressive Power of Adjudication, 2005 U. ILL. L. REv. 1043, 1045 n.4 (2005).

200. Balkin, supra note 195, at 10. Cf. Laurence H. Tribe, The Curvature of Constitutional Space: What Lawyers Can Learn from Modern Physics, 103 HARV. L. REV. 1, 2 (1989) (noting the "pervasive and profound role law plays in shaping our society and our lives").

201. The Corporate Abolitionists argue that the Court's affirmation of the corporate personhood doctrine encourages people to forget that corporations are created by legislatures and have only the powers granted by the state. Corporations 1, People 0, WOMEN's InT'L LeAgue For PEACE AND FREEDOM, http://www.wilpf.org/2010CvDOp EdLetter (last visited Oct. 17, 2011). For arguments that judges are expressionists, see Michelle Goodwin, Expressive Minimalism and Fuzzy Signals: The Judiciary and the Role of Law, 84 Chi.-Kent L. Rev. 19, 21 (2009); Jason Mazzone, When Courts Speak: Social Capital and Law's Expressive Function, 49 SYracuse L. REV. 1039, 1039-40 (1999); Sunstein, supra note 176, at 2028. 
but as artificial creations, or subordinate entities, it might significantly transform the way corporations are understood and treated. Thus, the Corporate Abolitionists' objective to strip corporations of the personhood designation stems from the belief that labels are not irrelevant. On the contrary, the Corporate Abolitionists assume those labels make an enormous difference in how we understand the world.

The language of legal doctrine is critical because it has a cultural force of its own to make things true and to bring into existence things that were not there previously. Although the utilization of the corporate personhood designation may seem indeterminate at times, it is not insignificant. ${ }^{202}$ Law does matter, and language matters too: "Each of us is partly made by our language, which gives us the categories in which we perceive the world ... and in remaking our language we contribute to the remaking of our characters and lives ...."203 The overriding goal of the Corporate Abolitionist movement is to remake our society and our lives by renaming corporations and removing them from the category of persons under the law. Once corporations are no longer viewed as persons but as subordinate objects, the Corporate Abolitionists believe a more democratic culture can be cultivated. This acknowledges that law and legal language are important tools for constructing cognitive frameworks and creating reality. The Corporate Abolitionists' call to revoke the personhood of corporations is grounded in concerns about the symbolic, expressive, and constitutive functions of the law. These concerns are not illegitimate, and in focusing so vigorously on legal labeling, the Corporate Abolitionists may be on to something. They know the law sends messages; they just want the law to send the right ones. We may disagree over what the right normative messages should be as a matter of policy and law, but in resolving that debate, perhaps we should pay closer attention to the signals law sends about social values. If the law affects the way we perceive our world and ourselves, then remaking the law of corporate personhood could indeed have substantial and far-reaching consequences.

The Corporate Abolitionists' efforts to amend the Constitution may not end in success, but the national conversation they are hoping to start about the legal doctrine of corporate personhood could influence the role

202. Blumberg, supra note 30 , at 324 .

[I]n the law, concepts have a life of their own because of their ability ex ante to influence the thinking of judges and ex post to be invoked by judges to justify their conclusions. These aspects of judicial decision making have clearly been evident in the judicial treatment of corporate personality in the constitutional cases [involving corporations] ....

Id.

203. James Boyd White, Justice as Translation: An Essay in Cultural and Legal CRITICISM 23 (1990). 
we allow corporations to have in our politics, our culture, and our society. This may not be such a bad thing. Evaluating and reevaluating the nature of constitutional personhood and the scope of constitutional rights is an important part of what makes our system of constitutional law so vibrant and essential. As the final section concludes, popular movements can have an important part in evolving interpretations of the Constitution, and in some ways, our legal system needs and thrives on the public's participation in the development of constitutional norms.

\section{Concluding Thoughts: The Role Of Social Movements IN CONSTITUTIONAL INTERPRETATION}

The Supreme Court's holding in Citizens United is one of the most controversial decisions in the history of corporate constitutional jurisprudence. In striking down federal restrictions on corporate campaign expenditures, the Court equated the First Amendment free speech rights of corporations with those of human beings, provoking outrage and opposition from many quarters. As a direct response to Citizens United, the Corporate Abolitionists' Move to Amend campaign represents an impassioned effort to mobilize a mass grassroots movement to amend the Constitution to abolish corporate personhood. Critics may scoff at the overly ambitious nature of the attempt, doubting that Corporate Abolitionists have any chance of attaining their objective. After all, amending the Constitution is no easy task, and many social movements of the past have failed in similar endeavors. ${ }^{204}$ Yet, even if the Corporate Abolitionists are unsuccessful in obtaining a constitutional amendment, they may find the same success that other social movements have had in contesting the Supreme Court's interpretation of the Constitution and transforming the meaning of the Constitution in the process.

Take the organized women's movement of the 1970s, for example. Although it failed in its effort to add the Equal Rights Amendment (ERA) to the Constitution to prohibit sex discrimination, the law today effectively looks much like it would had the ERA been adopted. For decades, the Supreme Court has interpreted the Constitution to forbid discrimination on the basis of gender, leading scholars to "commonly describe [the] failed constitutional amendment as a successful one."205 Similarly, although

204. See, e.g., Paul Taylor \& Philip G. Kiko, The Lost Legislative History of the Equal Rights Amendment: Lessons from the Unpublished 1983 Markup by the House Judiciary Committee, 7 U. MD. L.J. Race, Religion, Gender \& Class 341, 342-43 (2007) (describing the failed effort of the women's rights movement to push the Equal Rights Amendment through Congress).

205. Reva B. Siegel, Constitutional Culture, Social Movement Conflict and 
environmental activists never triumphed in securing constitutional protection for environmental quality, they succeeded in motivating widespread societal concern for environmental integrity and prompting the enactment of the entire environmental regulatory system in the United States, signifying "a transformation in American law that could be described as quasi-constitutional in scope." 206

A social movement's failure to amend the Constitution under Article $\mathrm{V}$ does not necessarily spell failure to change societal values and, ultimately, to change how the Constitution is interpreted. The Article V apparatus can be used as a political forum for expressing views and making arguments about what the Constitution does or should mean. ${ }^{207}$ Debate over whether to amend the Constitution can create a climate for citizens to wrestle with important constitutional issues. The scope and meaning of the Constitution is forged through disagreement and conflict over its interpretation, and popular movements that oppose the status quo help to shape the way the Constitution is applied over time. ${ }^{208}$ Social movements, such as the women's rights movement, the environmental movement, the civil rights movement, or the labor movement, all have a role in apprehending and igniting social change. They provide input and anger, opinions and outrage, and in the process of contesting established constitutional understandings, they have a voice in reforming the law.

In this sense, the law needs social movements just as social movements need the law. ${ }^{209}$ From the perspective of popular

Constitutional Change: The Case of the de facto ERA, 94 CAL. L. REV. 1323, 1332 (2006). See William N. Eskridge, Jr., Channeling: Identity-Based Social Movements and Public Law, 150 U. PA. L. REV. 419, 502 (2001) (noting that "the women's movement . . w was able to do through the Equal Protection Clause virtually everything the ERA would have accomplished had it been ratified and added to the Constitution"); David A. Strauss, The Irrelevance of Constitutional Amendments, 114 HARV. L. REV. 1457, 1476-77 (2001) ("Today, it is difficult to identify any respect in which constitutional law is different from what it would have been if the ERA had been adopted. For the last quarter-century, the Supreme Court has acted as if the Constitution contains a provision forbidding discrimination on the basis of gender.").

206. Coglianese, supra note 142, at 98; see id. at 108 (noting that the environmental movement is considered "one of the largest, and arguably the most influential, of all the social movements to arise in the last century"); Oakes et al., supra note 92, at 353-58 (noting that over the last several decades, many social movements supporting a variety of social causes have had a dramatic impact on altering social practices, laws, and the interpretation of constitutional provisions).

207. Siegel, supra note 205, at 1339; see also id. at $1368 \mathrm{n} .113$ (discussing the usage of Article $\mathrm{V}$ as a way of communicating with courts).

208. See, e.g., Reva B. Siegel, Text in Contest: Gender and the Constitution from a Social Movement Perspective, 150 U. PA. L. REV. 297, 303 (2001); Balkin, supra note 49, at 28; Balkin \& Siegel, supra note 27, at 928-29.

209. Balkin \& Siegel, supra note 27, at 946; Coglianese, supra note 142, at 85; Gerald Torres, Social Movements and the Ethical Construction of Law, 37 CAP. U. L. REV. 535, 581-82 (2009). 
constitutionalism, it is the people, not only the courts, that have active and ongoing involvement in the interpretation and enforcement of constitutional law. ${ }^{210}$ The belief that "We the People" are the authors of the Constitution's text motivates social movements to challenge judicial pronouncements of what the Constitution means. ${ }^{211}$ The mobilization of activist groups that define themselves around questions of constitutional reform operates under the assumption that courts are not entitled exclusively to say what the law is; ${ }^{212}$ the Constitution as a document belongs to the people and no institutional authority has the right to fix the Constitution's meaning. ${ }^{213}$

Whether this view of constitutional interpretation is the correct one is subject to debate. ${ }^{214}$ The Corporate Abolitionists certainly subscribe to this

210. See Larry D. Kramer, Popular Constitutionalism, Circa 2004, 92 CAL. L. REv. 959, 959-60 (2004) (describing the system of "popular constitutionalism" as contrasted with "legal constitutionalism"); see also Barry Friedman, Mediated Popular Constitutionalism, 101 Mich. L. REV. 2596, 2598 (2003) (describing popular constitutionalism as the idea that "judicial review should mirror popular views about constitutional meaning"); Doni Gewirtzman, Glory Days: Popular Constitutionalism, Nostalgia, and the True Nature of Constitutional Culture, 93 GEO. L.J. 897, 898-99 (2005) (describing the concept of popular constitutionalism). See also Theodore Ruger, Social Movements Everywhere, 155 U. PA. L. REV. PENNumbra 18, 18 (2006) (describing popular constitutionalism as "probably the most important development in the constitutional law academy over the past decade"); $i d$. at 19 (noting that the analysis of social movements can be considered one subset of popular constitutionalism).

211. Siegel, supra note 205, at 1355; Siegel, supra note 208, at 298. Ordinary citizens and elected officials feel authorized to talk about the meaning of the Constitution in a way that they do not feel authorized to speak about issues of tort or property law, for example. Siegel, supra note 208, at 322. This is because they see themselves as authors and interpreters of the Constitution. Id. at 345 .

212. In this regard, social movements engage in what has been called "protestant" constitutional interpretation. They do not accept the interpretations of courts as authoritative and final. SANFORD LEVINSON, CONSTITUTIONAL FAith 29 (1988) (A "protestant" approach to the Constitution "is based on the legitimacy of individualized (or at least nonhierarchical communal) interpretation ... while the catholic position is that the Supreme Court is the dispenser of ultimate interpretation ....").

213. Siegel, supra note 208, at 315, 344. See generally Torres, supra, note 209, at 536 (suggesting that law itself "could scarcely be authoritative (or even really law) if it were not seen to flow from the ultimate law givers. In a democracy, the ultimate law giver is 'the people."”)

214. Asserting a position of judicial supremacy, the Supreme Court predictably has rejected the proposition that anyone other than the Court has the power to interpret and enforce constitutional law. Nev. Dep't of Human Res. v. Hibbs, 538 U.S. 721, 728 (2003) (asserting "that it falls to this Court, not Congress, to define the substance of constitutional guarantees"); City of Boerne v. Flores, 521 U.S. 507, 536 (1997) ("When the Court has interpreted the Constitution, it has acted within the province of the Judicial Branch, which embraces the duty to say what the law is."). Under this view, judicial supremacy is essential precisely because of its counter-majoritarian nature. Rebecca L. Brown, Accountability, Liberty, and the Constitution, 98 CoLuM. L. REV. 531, 556 (1998); see also Larry Alexander $\&$ Frederick Schauer, On Extrajudicial Constitutional Interpretation, 110 HARV. L. REV. 
vision of the Constitution. They argue that the Supreme "[C]ourt can issue rulings, but We the People are the rulers." ${ }^{215}$ They reject the premise that judicial interpretations of constitutional issues are the final word: "[J]udgemade law is not democracy .... We the people have the power to change [it]." ${ }^{216}$ The Corporate Abolitionists dispute the Supreme Court's authority to establish what they call the "illegitimate legal doctrine of "Corporate Personhood." ${ }^{217}$ The Move to Amend campaign resolves to remedy this so-called "judicial usurpation of the people's sovereignty" by abolishing the constitutional standing and rights of corporations, thereby transforming long-standing interpretations of the Constitution. ${ }^{218}$ The movement's organizers characterize their efforts in populist terms: "[W]e are seizing the opportunity to exercise active control over our Constitution-not a document belonging to the Courts, nor to the Congress nor to the Chief Executive, but to us, the people's Constitution." ${ }^{219}$ The Corporate Abolitionists' rhetoric, like that of other social movements, invokes a commitment to popular constitutionalism and a call to citizens to participate in the reconstruction of constitutional meaning.

In this regard, is it possible that the Corporate Abolitionists' grassroots movement serves a useful purpose, whether or not its claims are entirely plausible and irrespective of whether it succeeds in its objective to obtain a constitutional amendment? By questioning and refuting the Supreme Court's interpretation of the Constitution, popular movements like that of

1359,1380 (1997). Critics of popular constitutionalism argue as a practical matter that it is unclear who "the People" are and what exactly they are supposed to do to engage in effective constitutional interpretation. Gewirtzman, supra note 210, at 900, 910.

215. Jim Hightower, Disclosing the Meekness of the 'DISCLOSE' Bill, ILLINOIS TIMES, June 3, 2010, http://www.illinoistimes.com/Springfield/print-article-7365-print.html.

216. What Could Change, supra note 152, at 15; see also Manski \& Graves, supra note 123 ("Beyond Congress and the Supreme Court, there is one remaining higher power, the power from which all authority in this country derives. This is the power of the American people to amend the Constitution and alter our form of government."); Corporate Personhood, RECLAIMDEMOCRACY.ORG, http://reclaimdemocracy.org/personhood/ (arguing that the premise of the Constitution is that "the people are the root of all power and authority for government").

217. Sopoci-Belknap, supra note 12. The Corporate Abolitionists contend that, with respect to the doctrine of corporate personhood, "[t]he Supreme Court is misguided in principle, and wrong on the law." MOVE TO AMEND, http://movetoamend.org/ (last visited Oct. 18, 2011).

218. Edwards \& Morgan, supra note 20. There is support for this type of activism in the body of popular constitutionalist scholarship. See, e.g., MARK TUSHnEt, TAKING THE CONSTITUTION AWAY FROM THE COURTS 194 (1999) ("[T]he public generally should participate in shaping constitutional law more directly and . . . reclaim [the Constitution] from the courts."); Kramer, supra note 210, at 960 (presenting the "radical position" that "we can, literally, take the Constitution away from the courts").

219. Mary Zepernick, On the History of Corporate Personhood and a Strategy for Overturning It, MOVE TO AMEND (Mar. 31, 2010), http://movetoamend.org/publicationstalks/zepernick-history-corporate-personhood-and-strategy-overturning-it. 
the Corporate Abolitionists keep the public engaged in constant dialog about contemporary constitutional issues. This dialogue refreshes society's understanding of the Constitution and promotes citizen attachment to and respect for our constitutional system. ${ }^{220}$ Democratic collective participation in resolving the important legal and political dilemmas of modern life helps to establish a sense of community and a shared investment in chosen outcomes. ${ }^{221}$ Although the Supreme Court, through controversial decisions like Citizens United, plays a large role in generating and advancing debate over important social and political issues, popular movements that rise up to dispute those decisions play a significant role in doing so as well. They keep the Constitution alive outside the courts, ${ }^{222}$ and every once in a while, they shape the direction of constitutional law by reorienting its meaning to shifting social values.

Social movements rarely succeed in completely realizing their supreme goals in law. ${ }^{223}$ The Corporate Abolitionists face formidable obstacles in trying to obtain a constitutional amendment, and we can speculate that the likelihood of their success is small. They press on, however, with the belief that even the most entrenched legal doctrines are not inevitable or divine. ${ }^{24}$ Certain social movements in history confirm this belief. As the civil rights movement and the women's rights movement demonstrated, "[I]n the fullness of time, utopian constitutional claims can ripen into constitutional orthodoxy . . .."225 The law has changed as society has changed, and constitutional principles are ever evolving with the times. Perhaps it is folly to dismiss the efforts of the Corporate Abolitionists prematurely, for one never knows what, if any, societal transformations can lie ahead.

In the end, Corporate Abolitionists may find that achieving their ultimate objective to amend the Constitution is beyond their reach. But, in the process of trying, they can spur a public conversation about the nature of corporate constitutional personhood that is relevant, even if they fail in

220. Siegel, supra note 205, at 1328-29.

221. Id. at $1341-43$.

222. The literature on social movements and popular constitutionalism speaks often of the life of the Constitution that exists outside the courts. See, e.g., Robert C. Post \& Reva B. Siegel, Legislative Constitutionalism and Section Five Power: Policentric Interpretation of the Family and Medical Leave Act, 112 YALE L.J. 1943, 2022 (2003) ("[T] Constitution lives a vibrant and consequential life outside the courts."); Siegel, Text in Context, supra note 208, at 300-01 (noting the "rapidly growing body of constitutional theory written in law schools that examines the life of the Constitution outside the courts").

223. Balkin \& Siegel, supra note 27, at 950.

224. Grossman \& Adams, supra note 139, at 18. Legal scholars have made related arguments. See, e.g., Millon, supra note 103, at 262 (" $[\mathrm{H}]$ istory should remind us that there is nothing inevitable about orthodoxy. Ideas about what corporations are, and the normative implications that follow from those ideas, have changed radically over time.").

225. Siegel, supra note 205, at 1411. 
their endeavor to eliminate it. Their concerns about the expressive function of legal statements raise significant questions about the type of world we want our laws to create - a world where a corporation is a person entitled to the same constitutional rights as individuals, or a world where corporate interests never trump or equal those of human beings. Should the expenditure of corporate money in American politics enjoy the same First Amendment protection that a man possesses to speak his mind in the public square? Does the doctrine of corporate personhood grant corporations too much power under the law? What kind of message do we want the law to send about the status of corporations in our society vis-à-vis individual citizens? These difficult questions are far too complex ever to be resolved once and for all. From the Supreme Court's 5-4 division in Citizens United, it is clear the Court itself is as divided as the rest of us on these controversial issues. Rather than arresting the debate over the scope of corporate constitutional rights and personhood, Citizens United has deepened the conversation and moved the discussion forward. The case may turn out to be only one skirmish in what will be a long battle over the meaning of the First Amendment and its relationship with corporate America. 